NEW EVIDENCE ON INVESTORS' VALUATION OF DEFERRED TAX LIABILITIES

by

John Russell Hamilton

Copyright $\odot$ John Russell Hamilton 2018

A Dissertation Submitted to the Faculty of the

\title{
DEPARTMENT OF ACCOUNTING
}

In Partial Fulfillment of the Requirements

For the Degree of

DOCTOR OF PHILOSOPHY

In the Graduate College

THE UNIVERSITY OF ARIZONA 


\section{THE UNIVERSITY OF ARIZONA}

\section{GRADUATE COLLEGE}

As members of the Dissertation Committee, we certify that we have read the dissertation prepared by John Russell Hamilton, titled 'New Evidence on Investors' Valuation of Deferred Tax Liabilities" and recommend that it be accepted as fulfilling the dissertation requirement for the Degree of Doctor of Philosophy.

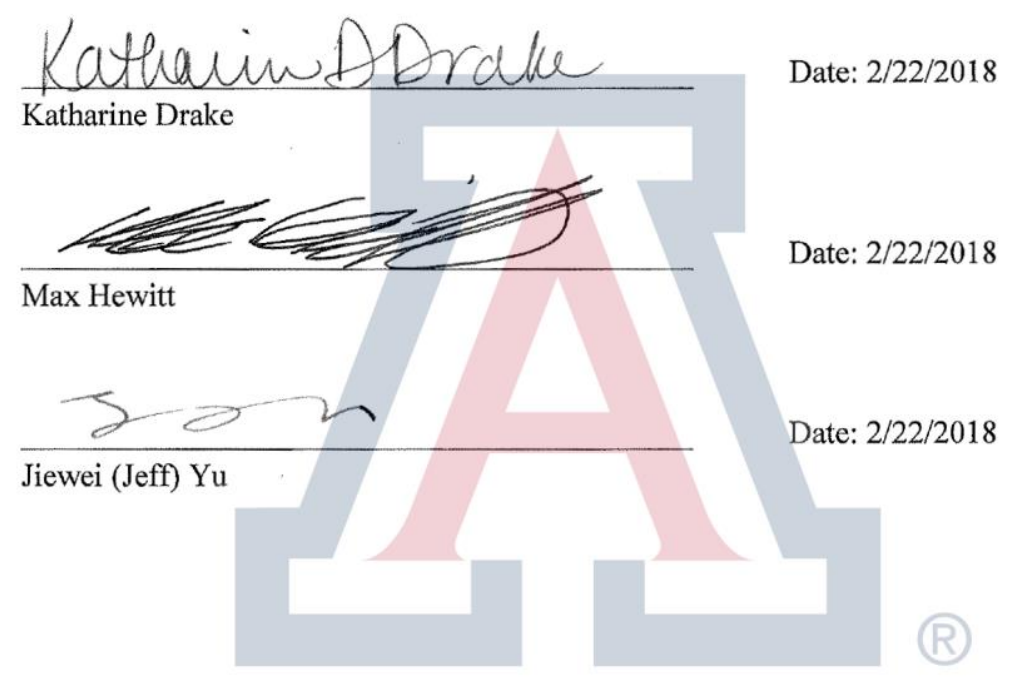

Final approval and acceptance of this dissertation is contingent upon the candidate's submission of the final copies of the dissertation to the Graduate College.

I hereby certify that I have read this dissertation prepared under my direction and recommend that it be accepted as fulfilling the dissertation requirement.

Ka thaune D Proke

Dissertation Director: Katharine Drake

Date: $2 / 22 / 2018$ 


\section{STATEMENT BY AUTHOR}

This dissertation has been submitted in partial fulfillment of the requirements for an advanced degree at the University of Arizona and is deposited in the University Library to be made available to borrowers under rules of the Library.

Brief quotations from this dissertation are allowable without special permission, provided that an accurate acknowledgement of the source is made. Requests for permission for extended quotation from or reproduction of this manuscript in whole or in part may be granted by the copyright holder.

SIGNED: John Russell Hamilton 


\section{ACKNOWLEDGEMENTS}

I appreciate the thoughtful suggestions and support of my dissertation committee, Katharine Drake (chair), Max Hewitt, and Jeff Yu. This study has also benefited from the comments of Lin Cheng, Dan Dhaliwal, Ryan Huston, Kathleen Kahle, Aaron Roeschley, Jake Thornock, and workshop participants at the University of Arizona, the University of North Texas, Southern Methodist University, as well as members of the Arizona Tax Reading Group. Some portions of the data collection were facilitated by Perl programs written by Andy Leone. 


\section{TABLE OF CONTENTS}

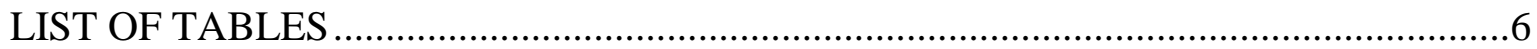

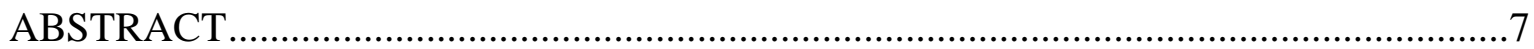

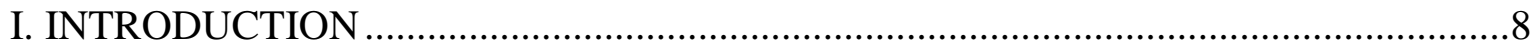

II. PRIOR LITERATURE AND HYPOTHESES DEVELOPMENT ..................................12

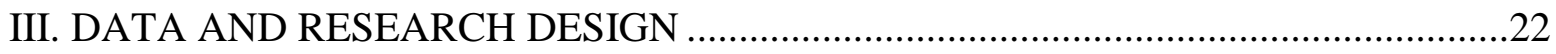

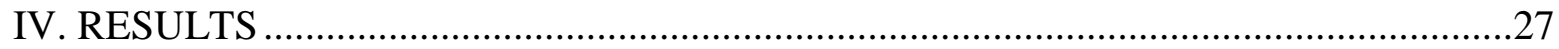

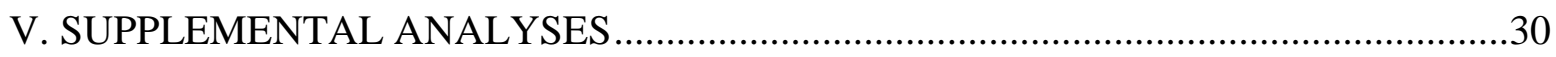

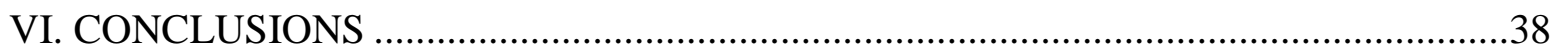

APPENDIX A, Panel A, General Deferred Tax Example ....................................................54

APPENDIX A, Panel B, Growing Deferred Tax Liability Example.....................................55

APPENDIX B, Deferred Tax Data Collected via Perl Scripts ………………………...........56

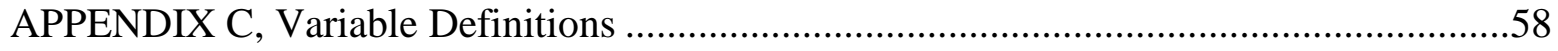

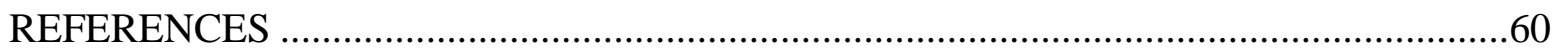




\section{LIST OF TABLES}

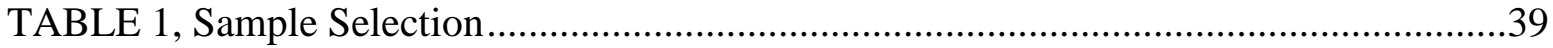

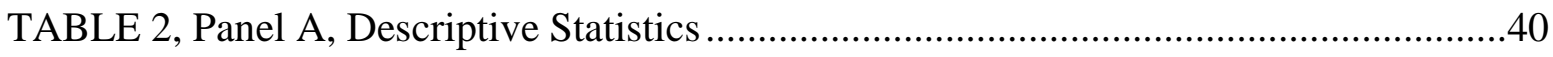

TABLE 2, Panel B, Descriptive Statistics, Means of Perl Data Set and Compustat Data Set.

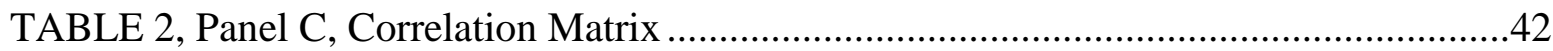

TABLE 3, Market Valuation of Deferred Tax Balance Sheet Components,

Panel A, H1: Recognition Hypothesis

TABLE 3, Market Valuation of Deferred Tax Balance Sheet Components,

Panel B, H2: Measurement-Account Growth

TABLE 3, Market Valuation of Deferred Tax Balance Sheet Components,

Panel C, H3: Measurement-Future Income

TABLE 3, Market Valuation of Deferred Tax Balance Sheet Components,

Panel D, H4: Measurement-Discounting ………………….........................................46

TABLE 4, Supplemental Analysis, Market Valuation of Deferred Tax Liabilities ...............48

TABLE 5, Supplemental Analysis, Current-Year Depreciation

DTL and Future Taxes Paid .50

TABLE 6, Market Valuation of Deferred Tax Balance Sheet Components, S\&P 500 Firms, Effect of Bonus Depreciation 


\begin{abstract}
Although deferred tax liabilities represent a significant liability for most firms, prior research provides mixed evidence concerning investors' valuation of these items. Using an expanded data set of hand-collected tax footnotes, I examine (1) whether investors recognize depreciation-related deferred tax liabilities as economic burdens, and if so, (2) how investors measure the effect of these liabilities. I find evidence suggesting that investors price depreciation-related deferred tax liabilities as economic burdens and show that my primary findings are robust to the use of a changes-based methodology. I also examine various factors that could affect investors' measurement of these liabilities. In doing so, I develop a new method to identify tax-sensitive firms to implement my tests. This method incorporates forward-looking profit expectations without a look-ahead bias. Finally, I provide evidence of circumstances where investors discount deferred tax liabilities despite current accounting standards prohibiting managers from discounting these deferred tax liabilities in the reported financial statements. As depreciation-related deferred tax liabilities are among the largest and most common deferred tax liabilities, my study provides important insights into investors' valuation of firms' tax planning.
\end{abstract}




\section{INTRODUCTION}

Do deferred tax liabilities (DTLs) represent economic burdens to firms? For the most common and largest DTLs (i.e., those associated with accelerated tax depreciation), prior empirical research finds little association between these liabilities and stock prices. However, analytical research suggests that DTLs represent economic burdens that should negatively affect firm value. My study attempts to resolve this conflict in the academic literature by reexamining the relation between depreciation-related DTLs and firm value.

I focus on depreciation-related DTLs for several reasons. First, virtually every firm has depreciation-related DTLs. Next, depreciation-related DTLs are relatively large (mean value of $\$ 1.13$ per share in my sample), suggesting that these liabilities are economically significant. In addition, prior research suggests that the valuation of depreciation-related DTLs involves complexities not associated with other temporary tax differences, such as discounting, perpetually growing liability balances, etc. Finally, tax legislation passed in December, 2017 will likely increase the relative size of depreciation-related DTLs, relative to other deferred tax items. ${ }^{1}$ Thus, depreciation-related DTLs are an important setting to examine investor valuation of DTLs.

While prior empirical research has previously examined the relation between DTLs and stock prices, my approach benefits from three innovations to provide new insights about investor valuation of DTLs. First, I develop a Perl script that collects a large and unique data set of firms'

\footnotetext{
${ }^{1}$ The tax law reduces the statutory tax rate on U.S. firms from 35 percent to 21 percent, which will decrease the reported magnitude of all U.S.-based deferred tax assets and liabilities. However, the new law also increases the bonus depreciation amount from 50 percent to 100 percent, which will increase the size of deferred tax liability associated with future asset purchases. Thus, for most firms, depreciation-related deferred tax amounts will become a larger share of total deferred tax amounts.
} 
depreciation-related DTLs. This larger data set allows for cross-sectional testing of the various theories about whether and how investors value DTLs. Second, I choose a setting that includes years with bonus tax depreciation, i.e., years that contain the highest levels of depreciationrelated DTLs. Larger depreciation-related DTLs increase the likelihood of finding a relation with stock prices, assuming such a relation exists. ${ }^{2}$ Finally, I develop an innovative method for separating tax-sensitive firms from tax-insensitive firms based on valuation allowances. ${ }^{3}$ This method allows me to limit my analysis to the cross section of firms for which depreciationrelated DTLs should be most value relevant.

I organize my theoretical framework by considering prior research examining (1) investors' recognition of depreciation-related DTLs as economic burdens and (2) investors' measurement of depreciation-related DTLs. ${ }^{4}$ I first examine whether depreciation-related DTLs are value relevant, i.e., whether investors recognize these accounting liabilities as an economic burden when valuing firms. After presenting evidence consistent with investors recognizing DTLs, I examine the specific factors investors potentially consider when measuring the value of DTLs.

\footnotetext{
${ }^{2}$ Because the new tax law increases bonus depreciation from 50 percent to 100 percent, my focus on years with bonus depreciation should have continuing relevance. Note that, for new asset purchases, the dollar amount of the deferred tax liability may be larger under the new law, despite the reduction in the statutory tax rate. For example, a $\$ 100,000$ asset placed in service in 2017 would have first year tax depreciation of $\$ 100,000 * 0.5=\$ 50,000$ bonus tax depreciation plus $\$ 50,000 * 0.1429$ (depreciation rate for seven-year tax property) $=\$ 57,145$ total tax depreciation deductions, which at a 35 percent tax rate, generates a 20,000 DTL (ignoring GAAP depreciation). A similar calculation in 2018 would be $\$ 100,000$ total tax depreciation $* 21$ percent tax rate $=\$ 21,000$ DTL (again, ignoring GAAP depreciation). Thus, for at least some classes of assets, DTL balances for depreciation may remain relatively high for some firms, despite the drop in the tax rate, at least for new asset additions.

${ }^{3}$ Finley, Ribal, and Weisbrod (2017) use a similar approach to identify full valuation allowance firms.

${ }^{4}$ These two concepts are central to the FASB's Conceptual Framework (FASB 1984, 2008, 2010). However, the Conceptual Framework is the underpinning for financial accounting, not valuation. Nevertheless, the Conceptual Framework states, "(g)eneral purpose financial statements are not designed to show the value of a reporting entity, but they provide information to help existing and potential investors, lenders, and other creditors to estimate the value of the reporting entity" (FASB 2010, paragraph OB7).
} 
To analyze whether investors recognize DTLs when valuing firms, I employ a model similar to Amir, Kirschenheiter, and Willard (1997) and Laux (2013). I include three empirical innovations when using this model: (1) utilization of a larger data set gathered via a Perl script, (2) inclusion of years with bonus depreciation in my sample period, and (3) consideration of the tax sensitivity of each firm-year observation. I find a strong association between depreciationrelated DTLs and stock prices, suggesting that investors recognize these liabilities as economic burdens. My results contrast with the findings of Laux (2013) and Dotan (2003), which suggest that depreciation-related DTLs are not value relevant. These studies argue that depreciationrelated DTLs are not value relevant because they are associated with prior — and not future - taxrelated cash flows. However, my results suggest that investors value depreciation-related DTLs as economic burdens, and thus I also examine cross-sectional differences in how investors value these DTLs.

With respect to measuring investor pricing of depreciation-related DTLs on firm value, I examine several factors considered in the prior literature: DTL account growth, future income, and discounting. First, I examine investor pricing of increasing (growing) DTLs. Amir et al. (1997) suggest that when investors expect depreciation-related DTLs to continue to increase (anticipating future purchases of depreciable property) investors discount depreciation-related DTLs to near zero. This explanation suggests that if the balance of DTLs never declines, then these liabilities will not translate into future cash tax payments and thus are not value-relevant. In contrast, analytical research argues that DTLs are an economic burden even if their balance never declines (Sansing 1998; Guenther and Sansing 2000). I find evidence consistent with investors valuing depreciation-related DTLs as economic burdens even when the balance is increasing. 
The second measurement factor I examine involves whether investors price DTLs differently depending on expectations of the firm's future taxable income. Under APB 11 (APB 1967), the prior accounting standard for income taxes, Givoly and Hayn (1992) use firm history of tax losses to predict future tax losses and find that investors place less weight on DTLs when firms are less likely to incur future cash tax outflows. Consistent with their finding, I find a similar investor pricing effect on DTLs reported under the present accounting standard for income taxes (ASC 740; FASB 1992).

The final measurement factor I examine is investor discounting of DTLs. Prior analytical research contends that the value of depreciation-related DTLs is a function of tax depreciation rates and cost of capital rates (Sansing 1998; Guenther and Sansing 2000). While I find some empirical evidence consistent with investors discounting DTLs, this discounting appears to be more consistent with GAAP-tax depreciation reversal periods than tax depreciation periods.

In addition to my primary price-level tests, in supplemental analyses I employ a changesbased methodology using the cash valuation framework developed by Faulkender and Wang (2006). I expand their model to include both changes in depreciation-related DTLs and the levels of depreciation-related DTLs. Consistent with my main findings, I provide additional evidence suggesting that investors view changes in DTLs as changes in economic burdens.

I also attempt to reconcile my study's results with the findings of prior empirical studies. One key difference between my sample and the samples used in prior empirical studies is the widespread presence of bonus tax depreciation during my sample period; prior empirical studies employed sample periods when little or no bonus depreciation was in effect. Bonus depreciation further accelerates tax depreciation deductions, resulting in larger depreciation-related DTL balances. In supplemental analyses, I find that the presence of bonus tax depreciation is an 
important driver of my results. As bonus tax depreciation changes the amount, but not the nature, of DTLs, my study arguably provides a more powerful setting to examine the relation between DTLs and firm value. Additionally, because the new tax law expands the bonus depreciation percentage from 50 to 100 percent, the results of my study should continue to be relevant.

My study should be of interest to investors, researchers, tax advisors, and managers by providing insight into how investors value tax deferral planning effort. Given that I find that some evidence that investors discount depreciation-related DTLs based on expected reversals when valuing firms, this study may also provide insight to standard setters, which currently prohibit discounting of deferred taxes. Finally, I present a new method for researchers to separate tax-insensitive firms from tax-sensitive firms. My approach uses Compustat data to identify taxinsensitive firms by taking into account forward-looking profit expectations without a lookahead bias. This method is arguably particularly useful for future research in the study of loss firms, an area that has yet to be fully explored (Hanlon and Heitzman 2010).

\section{PRIOR LITERATURE AND HYPOTHESES DEVELOPMENT}

\section{Accelerated Tax Depreciation and DTLs}

I focus my study of investor pricing of DTLs on depreciation-related amounts for three key reasons. First, unlike some other, less-common temporary differences (e.g., installment sales), depreciation-related DTLs affect almost every firm. Second, depreciation-related DTLs are economically significant. For example, firms in my sample report mean (median) DTLs associated with accelerated tax depreciation of $\$ 1.13(\$ 0.22)$ per share. Finally, prior analytical research focuses extensively on the unique valuation issues associated with depreciation-related DTLs (e.g., varying reversal periods, perpetually growing liability balances, etc.). By focusing 
on these more complex DTLs, my results are arguably more generalizable than might be obtained by limiting my study to simpler DTLs that occur in a limited number of firms.

While GAAP depreciation is based on the estimated lives of depreciable assets, tax depreciation is based on the tax law. For federal income tax purposes, depreciation is governed by the Internal Revenue Code (IRC). In addition to mandating tax depreciation lives that are often shorter than economic lives, the IRC also allows for bonus depreciation. ${ }^{5}$ Thus, it is very common for cumulative tax depreciation deductions to exceed cumulative GAAP depreciation deductions. However, for any individual depreciable asset, the cumulative expense under both systems will be eventually the same over the life of the asset.

Under SFAS 109, Accounting for Income Taxes (codified as ASC 740), a firm's tax expense consists of two parts: a current tax expense (largely the cash tax payable computed according to the tax law) and deferred tax expense. The deferred tax expense takes into account differences between the GAAP and tax recognition of assets and liabilities, including differences in the depreciation of assets. When a firm depreciates an asset more rapidly for tax purposes than GAAP purposes, the firm reduces its income taxes payable and thus its current tax expense. This depreciation expense difference also causes the net tax basis of the depreciable asset to fall below the asset's GAAP carrying amount, resulting in the recognition of DTLs. In this example, the higher deferred tax expense offsets the reduced current tax expense. In later years of the asset's life, GAAP depreciation exceeds tax depreciation. As a result, current tax expense increases and deferred tax expense decrease by the same amount (assuming no future asset

\footnotetext{
${ }^{5}$ In Section V, I examine the effect of bonus depreciation on my primary results. In contrast, prior empirical research examines samples containing years with little or no bonus tax depreciation deductions.
} 
purchases). ${ }^{6}$ The DTLs created by the differences in GAAP and tax depreciation are the focus of my study. See Appendix A for an illustration of these effects.

Prior research offers a variety of conflicting theories regarding investor valuation of DTLs, especially depreciation-related DTLs. I organize the discussion of these disparate explanations by considering (1) investors' recognition of depreciation-related DTLs as economic burdens, and (2) investors' measurement (i.e., pricing) of depreciation-related DTLs.

\section{Investors' Recognition of Depreciation-related DTLs as Economic Burdens}

Laux (2013) and Dotan (2003) are two studies that consider whether investors recognize depreciation-related DTLs as economic burdens. These studies suggest that certain types of deferred taxes are value relevant; however, other types of deferred taxes have no valuation implications and are not recognized as economic burdens by investors. The authors suggest that "GAAP-First temporary differences" (generated whenever the GAAP recognition of a transaction precedes the tax recognition of the same event) are value relevant, because they are predictive of future tax payments. For example, if income is fully recognized for GAAP but deferred for tax under the installment sale method, then the resulting DTLs are necessary to account for taxes payable in the future.

In contrast, both Laux (2013) and Dotan (2003) argue that "Tax-First temporary differences" (generated when the tax rules recognize an event prior to GAAP, including accelerated tax depreciation) do not generate value-relevant deferred tax assets or liabilities. The authors argue that Tax-First temporary differences are not predictive of future tax deductions and

\footnotetext{
${ }^{6}$ In practice, firms hold multiple depreciable assets purchased over a series of years, making the calculation of the net DTLs more complex. The question as to whether investors view DTLs on a depreciable-asset basis, or an account-level basis, is discussed in more detail below.
} 
future tax-related cash flows. ${ }^{7}$ Accordingly, DTLs from accelerated tax depreciation are not value relevant to investors because these DTLs do not represent any future tax cash flows. Applying this argument, measurement problems are moot because investors do not recognize DTLs associated with accelerated tax depreciation as economic burdens.

Using a hand-collected sub-sample of S\&P 500 firms, Laux (2013) examines the relation between deferred tax balances and future cash tax payments. His analysis shows that the incremental predictive power of deferred taxes on future cash flows is small but statistically significant. Consistent with the predictions of Dotan (2003), he shows that GAAP-First temporary differences are associated with future taxes paid, whereas Tax-First temporary differences are not associated with future taxes paid. In a supplemental analysis, Laux (2013) shows statistically-significant stock price valuation coefficients on GAAP-First deferred taxes. However, he does not find a statistically-significant association between stock prices and TaxFirst deferred taxes. Finally, Laux (2013) examines a specific Tax-First item, depreciationrelated DTLs. Consistent with his predictions that Tax-First temporary differences are not value relevant, Laux (2013) does not find evidence suggesting that investors price depreciation-related DTLs.

One potential challenge to the arguments presented by Laux (2013) and Dotan (2003) is that the authors assume that Tax-First temporary differences cannot be predictive of future tax cash flows. In fact, firms that deduct accelerated tax depreciation in one year face higher cash taxes in the future compared with firms that have taken a more conservative approach to

\footnotetext{
${ }^{7}$ Consider a firm that purchases a $\$ 100$ asset taking $\$ 60$ tax depreciation and $\$ 10$ GAAP depreciation in the year of acquisition. This depreciation-related difference creates DTLs equal to $\$ 50$ multiplied by the tax rate of 40 percent, i.e., \$20. Laux (2013) and Dotan (2003) highlight that these DTLs do not represent future tax deductions - instead, they represent prior excess of tax over GAAP expenses. The authors argue that, as these DTLs do not represent future tax deductions, they do not represent future cash tax payments and are thus not value relevant to investors.
} 
deducting tax depreciation. Thus, relative to an otherwise identical firm without DTLs, a firm with DTLs will incur higher future cash outflows (assuming that the DTLs reverse over the observed time period and both firms are sufficiently profitable). To the extent that current year depreciation-related DTLs map into future taxes paid (either positively or negatively), I argue that investors will value DTLs as an economic burden.

In Appendix A, Panel A, General Deferred Tax Example, I present a simple illustration of two identical firms, Firm A and Firm B. The essence of the illustration is that in Year 1, Firm A reduces its cash taxes paid via accelerated tax depreciation, while Firm B claims no tax depreciation during the year. At the end of Year 1, Firm A will have more cash on its balance sheet, but it will also have a higher DTL balance than Firm B. If investors observe and value the extra cash on Firm A's balance sheet, but fail to value the DTLs that offset the extra cash, then investors would mistakenly ascribe more value to Firm A than to Firm B. This effect would occur even though the firms have identical balance sheets a year later, when Firm B's cumulative tax deprecation equals the amount of Firm A.

Thus, while Laux (2013) and Dotan (2003) argue that depreciation-related DTLs relate to prior cash tax payments should not be priced by investors, I expect that these DTLs also provide information about a firm's future cash tax flows relative to other firms. Specifically, depreciation-related DTLs suggest that future cash taxes will be higher compared with similar firms without depreciation-related DTLs. Thus, I examine the following hypothesis.

H1: Recognition Hypothesis: Investors price depreciation-related DTLs as economic burdens.

\section{Investors' Measurement of Depreciation-related DTLs}

Assuming that investors recognize depreciation-related DTLs as economic burdens, I next address how investors measure (i.e., price) the economic burdens stemming from these 
liabilities. Existing research provides a variety of approaches that investors might plausibly employ to measure the effect of these liabilities. I first examine whether investors appear to focus on DTL reversal at the account or asset level. If investors consider DTL reversals at the account level, then firm with increasing levels of DTLs should have minimal pricing effects for DTLs, since the conversion of the DTL into tax-related cash outflows appears to be indefinitely postponed. On the other hand, if investors price reversals of DTLs on an asset basis, then the effect on pricing should be more significant. One prior empirical study that considers this question is Amir et al. (1997). Using a hand-collected sample of firms from the Fortune 500, the authors find that deferred tax assets associated with restructuring charges (which are expected to reverse quickly) have a higher valuation coefficient than deferred tax assets associated with environmental liabilities or employee benefits (which are expected to have longer reversal periods). They find that the valuation coefficient on deferred taxes related to depreciation approaches zero and they suggest their finding reflects investor expectations of continued DTL growth due to asset purchases, which would suggest that investors price depreciation-related DTLs on an account basis. ${ }^{8}$

While the Amir et al. (1997) view of investor pricing of depreciation-related DTLs may appear indistinguishable from the reasoning of both Laux (2013) and Dotan (2003) (i.e., these studies all predict zero, or near zero, valuation coefficients for depreciation-related DTLs), the Amir et al. (1997) explanation yields different predictions for the cross-section of firms that are no longer growing their depreciable assets. In other words, under the Amir et al. (1997)

\footnotetext{
${ }^{8}$ While Laux (2013) fails to find a significant valuation coefficient for depreciation-related DTLs, Amir et al. (1997) find a small positive valuation coefficient that is statistically different than zero in a pooled specification. However, Amir et al. (1997) note that the statistical significance is primarily driven by a single year in their study, i.e., the year in which firms self-selected into early adoption of FAS 109. Thus, throughout the study, the authors report that they find a valuation coefficient for depreciation-related DTLs that is "close to zero."
} 
explanation, after a firm begins to slow its acquisitions of depreciable assets, DTLs will begin to decline and the firm will incur cash taxes payable. Thus, the arguments in Amir et al. (1997) suggest that the stock prices of non-growing firms will reflect DTLs as an economic burden, whereas the Laux (2013) and Dotan (2003) Tax-First approach suggest that investors will not value the depreciation-related DTLs of these firms. However, under the Amir et al. (1997) explanation, for firms with growing DTLs, cash taxes are deferred indefinitely. In essence, Amir et al. (1997) suggest that depreciation-related DTLs are recognized by investors; however, the measurement of these liabilities is effectively zero for growing firms.

Lynn, Seethamraju, and Seetharaman (2008) specifically consider the valuation implications of the foreseeability of reversals of DTLs. United Kingdom former accounting standard SSAP No. 15 (Accounting Standards Committee 1985) required firms to record all DTLs that were expected to "crystalize" (i.e., reverse) over a short period of time (typically three to five years). SSAP No. 15 required that all firms disclose other longer-lived DTLs in the footnotes, but not record these amounts as liabilities. The authors find evidence that investors price both the recorded and disclosed DTLs and that they price these two sets of DTLs approximately equally, suggesting that in their setting, neither the Tax-First notion of Laux (2013) and Dotan (2003), nor the account growth notion of Amir et al. (1997), explain investor valuation of DTLs. However, the study does not examine whether investors price growing DTLs differentially than non-growing DTLs, nor does it focus specifically on depreciation-related DTLs.

Relatedly, analytical research suggests that the relevant frame of reference is not the overall balance of DTLs, but depreciation-related differences associated with individual assets. Under this explanation, GAAP-tax depreciation differences for individual assets continuously 
reverse; however, this reversal is more than offset by larger originating GAAP-tax differences arising from future fixed asset purchases. For example, Sansing (1998) creates valuation models suggesting that DTLs associated with accelerated tax depreciation represent economic burdens even if the net balance of DTLs never appears to reverse because of future depreciable asset additions. This perspective suggests that depreciation-related DTLs are value relevant, regardless of whether the balance is growing.

To provide additional intuition for my hypothesis that investors price depreciation-related DTLs, even when those DTLs are growing, consider Appendix A, Panel B, Growing Deferred Tax Liability. In this example I modify the example in Panel A by having both firms acquire additional assets in Year 2, resulting in growing balances of both net property and DTL. The key insight from this example is that Firm A's DTL is converted into incremental cash outflows (compared to Firm B) in Year 2, even though Firm A has a growing DTL balance. In other words, taking additional tax accelerated depreciation Year 1 results in higher tax cash outflows in Year 2, and not, as might be expected, at some distant point in the future when the balance of the DTL account begins to decline. This outcome is consistent with the approach of Sansing (1998), since future asset additions do not postpone the negative cash flow implications of individual asset depreciation reversals. As a result, I examine the following hypothesis.

H2: Measurement-Account Growth Hypothesis: Investors price depreciation-related DTLs as economic burdens, regardless of whether the balance of DTLs is growing.

One potential factor affecting investor measurement and valuation of depreciation-related DTLs is the expectation of firms' future taxable income. Generally, when a firm's DTL reverses, taxable income (and cash taxes payable) increase. However, if a DTL reverses in a period when a firm has a substantial tax loss, the incremental tax outflows from the DTL reversal may be small 
or zero. In other words, if a firm fails to generate sufficient future taxable income, DTLs will not result in higher future cash tax payments and therefore may not be value relevant.

Givoly and Hayn (1992) test this notion by examining whether investors consider the likelihood of future taxable income when pricing DTLs, using a firm's history of losses to proxy for the likelihood that a firm will fail to have future taxable income. Their study finds evidence that, as the likelihood of future losses increase, investors ascribe lower values to DTL amounts. This finding is consistent with the notion that DTLs only represent economic burdens if their future reversal result in incremental tax-related cash outflows.

Importantly, Givoly and Hayn (1992) focus on DTLs computed under APB 11, rather than the current accounting standard, SFAS 109/ASC 740. Under the prior tax accounting standard, firms did not disclose the depreciation-related portion of DTLs. Thus, Givoly and Hayn (1992) do not focus on investors' valuation of depreciation-related DTLs. ${ }^{9}$ In addition, because of differences in the measurement of the deferred tax assets and liabilities under the prior and current standards, it is not clear what inferences can be drawn from the empirical results involving the prior standard. ${ }^{10}$ Nevertheless, I predict that the likelihood of future income criteria employed by Givoly and Hayn (1992) is descriptive of investors' valuation of DTLs under the current accounting standard. Accordingly, I examine the following hypothesis.

H3: Measurement-Future Income Hypothesis: Investors' pricing of DTLs is affected by their expectations of firms earning future taxable income.

\footnotetext{
${ }^{9}$ Under the superseded APB 11, deferred tax assets/liabilities are simply a residual entry that is made after recording the proper GAAP tax expense on the income statement. Over time, the residual deferred tax asset or liability increases or decreases, but as it is a 'plug', there is no way to determine how much of the total balance at any given point relates to any existing temporary difference, e.g., depreciation. In contrast, SFAS 109/ASC 740 is a balancesheet based approach and the financial statement tax footnote delineates the nature of the deferred tax asset and liability balance by type of temporary difference.

${ }^{10}$ See Ayers (1998) for further discussion of the differences between the two income tax accounting standards.
} 
A final measurement consideration arises from discounting, meaning that investors discount DTLs on the balance sheet for the time value of money. ${ }^{11}$ Discounting presents a unique challenge to DTLs, as other long-term liabilities are typically measured using net present value methodologies. ${ }^{12}$ Sansing (1998) models the value of DTLs associated with accelerated tax depreciation and finds that these amounts represent economic burdens. This finding holds even in cases where the net balance of DTLs is growing and does not reverse because of future depreciable asset additions. His analysis suggests that the economic value of DTLs is the product of the GAAP depreciation-related DTLs and the factor, $\sigma /(\sigma+p)$, where $\sigma$ is the tax depreciation rate and $p$ is the cost of capital. In his model, the GAAP reversal period is not relevant; only the tax depreciation rate (and cost of capital) is relevant to the discount calculation.

Similarly, Guenther and Sansing (2000) use a model to show that the GAAP reversal period of a deferred tax temporary difference is not relevant to firm value, as the reversal period is dependent on the GAAP depreciation timing (that is unrelated to tax-related cash flows). Thus, they show that while the timing of the tax deduction rates and cost of capital rates are relevant to investor pricing, the GAAP treatment of the underlying temporary item is not value relevant. They also suggest that DTLs associated with accelerated tax depreciation are a valuation adjustment to reconcile an asset's replacement cost to its value to the firm. In other words, if the asset is disposed of at its GAAP value, the DTLs will be transformed into a cash tax payable, suggesting that the DTLs are value relevant.

\footnotetext{
${ }^{11}$ Under SFAS 109/ASC740, as well as the prior standard (APB 11), discounting of DTLs is explicitly prohibited. The rule prohibiting discounting of DTLs appears to arise from concerns regarding measurement and implementation rather than from conceptual arguments that DTLs should not be discounted (FASB 1992, paragraph 199). This accounting rule does not mean, however, that stock prices do not reflect the effects of discounting.

${ }^{12}$ Consider, for example, defined benefit plans (ASC 715-30) and other post-retirement benefits (OPEB) (ASC 71560). GAAP explicitly requires discounting to measure these items.
} 
In a follow-up analytical study, Guenther and Sansing (2004) show, consistent with Sansing (1998), that the economic value of depreciation-related DTLs is strictly a function of the tax depreciation rate and the discount rate. They also conclude that the timing of the reversal (which is partially a function of the GAAP depreciation rate) is irrelevant to valuing DTLs. In contrast, Amir, Kirschenheiter, and Willard (2001) present analytical models showing that the reversal rate of the GAAP-tax depreciation difference affects the valuation of DTLs.

Empirically, Givoly and Hayn (1992) present evidence consistent with investors discounting DTLs based on expected reversal periods. ${ }^{13}$ Similarly, in Appendix A, Panel A, I suggest that the expected reversal period is relevant for investors valuation of DTLs even though the GAAP-tax reversal period for the firm with accelerated depreciation for tax purposes is driven solely by the GAAP timing of depreciation expense. Based on this reasoning, I examine the following hypothesis.

H4: Measurement-Discounting Hypothesis: Investors' pricing of DTLs is reduced as the expected time period of the temporary difference reversal increases.

\section{DATA AND RESEARCH DESIGN}

\section{Depreciation-related DTLs Data Collection}

A key focus of my analyses is the portion of DTLs attributable to differences in GAAP and tax depreciation. Tax depreciation is generally more rapid than GAAP depreciation, resulting in financial statement balances of net depreciable assets that exceed the tax basis of those same assets. This excess of GAAP basis over tax basis for depreciable assets generates DTLs, which are categorized as noncurrent DTLs on the balance sheet. ${ }^{14}$ These DTLs related to depreciation

\footnotetext{
${ }^{13}$ As noted above, Givoly and Hayn (1992) does not consider depreciation-related DTLs, and their results are based on deferred taxes computed under the prior accounting standard, APB 11.

${ }^{14}$ Under FAS 109/ASC 740, the timing of the reversal period is not relevant when determining whether the related deferred tax asset or liability is current or noncurrent. Such determination is based on the current or noncurrent
} 
are noted in the tax footnotes of financial statements but they are not currently available to researchers in a structured database. To collect this information, I create a Perl script that searches downloaded 10-K filings, collecting the depreciation amounts related to DTLs from the tax footnote. See Appendix B for details of the Perl data collection process.

\section{Sample Selection}

In Table 1, I summarize my sample selection procedure. I begin with 111,814 firm-year observations in years 2005-2014 from Compustat. I begin my sample in 2005, as this is the first year in which 10-K filings are widely available on the SEC website in the HTML format required by my Perl script. Following Bauman and Shaw (2016), I further limit my sample to firms traded on a major exchange (i.e., NYSE, AMEX, NASDAQ) that have more than ten million shares outstanding and a share price of at least one dollar per share. I include these restrictions to limit the analysis to firms that have liquid, readily tradable stock, which I expect to exhibit relative high levels of pricing integrity from investors. These restrictions reduce the sample to 43,861 observations. Consistent with the tax literature, I exclude financial firms (SIC codes 6000 to 6099), utilities (SIC codes 4900 to 4999), and REITs (SIC code 6798). After removing these industries and firm years missing values needed to compute control variables for the model, my sample consists of 26,017 observations. My Perl script (see Appendix B for details of the procedure) extracts validated depreciation-related DTLs for 8,898 of these observations (matching approximately 34 percent), and these matched firm years are the basis for my primary analyses that follow.

nature of the underlying asset or liability. However, for fiscal years beginning after December 15, 2016, Accounting Standards Update 2015-17 requires firms to collapse the current and noncurrent deferred tax balances into a single noncurrent account on the balance sheet (FASB 2015). 
I note that because of the efficiencies of the Perl script, the 8,898 firm-year sample size for this study is substantially larger than either Amir et al. (1997) or Laux (2013), each of which has less than 2,800 firm-year observations. In addition, my sample is not limited to Fortune 500 or S\&P 500 firms, as was necessary in those prior studies due to the limitations of hand collection.

In Panel A of Table 2, I provide descriptive statistics for the data expressed on a pershare basis. I define all variables in Appendix C, and I winsorize all continuous variables at 1 and 99 percent each year to reduce the effects of outliers. Consistent with prior studies, I note that the mean and median of net financial assets $(N F A)$ are both negative, indicating that firms in my sample have more debt outstanding than financial assets. I also note that DTLs associated with accelerated tax depreciation $\left(D E P R \_D T L\right)$ have a mean (median) value of $\$-1.13(\$-0.22)$ per share, suggesting that this liability is substantial in size and potentially economically important. Since depreciation-related DTL is a component of noncurrent deferred taxes, I construct the variable $N E T \_D E F E R R E D \_L T$ as the residual of noncurrent deferred taxes after the depreciation-related DTL is removed. The resulting value of NET_DEFERRED_LT can be either positive or negative. ${ }^{15}$

In Panel B of Table 2, I compare 8,898 observations with Perl data to the balance of the 26,017 Compustat observations for which Perl was not able to capture depreciation-related DTL amounts. A t-test reveals that for many variables, the difference in means between the two samples is not statistically different from zero, although there are differences for the variables of

\footnotetext{
${ }^{15}$ Under ASC 740, noncurrent deferred tax assets and liabilities for each taxing jurisdiction are netted together for presentation on the balance sheet. Thus, if a firm has a $\$ 100$ noncurrent deferred tax asset and a $\$ 250$ depreciationrelated noncurrent deferred tax liability, the financial statements would reflect a $\$ 150$ deferred tax liability. In that case, I would compute a NET_DEFERRED_LT balance of $\$ 100$, which would be a positive amount (i.e., asset) and subsequently be scaled by the number of shares.
} 
PRICE, NOA, AE, DTA_ST, DTL_ST. I also note that the firms in the Perl sample have a smaller value for SIZE than the non-Perl sample, measuring SIZE by the log of total assets. In the Supplemental Analyses section of this paper, I consider the effect of differences in size and profitability on my results.

\section{Valuation of Depreciation-related DTLs}

To analyze my first three hypotheses examining the relation between depreciation-related DTLs and stock prices, I employ the following model based on the models of Feltham and Ohlson (1995), employed by both Amir et al. (1997) and Laux (2013):

$$
\begin{aligned}
\text { PRICE }_{i, t} & =\beta_{0}+\beta_{1} N O A_{i, t}+\beta_{2} N P P E_{i, t}+\beta_{3} N P E N S I O N N_{i, t}+\beta_{4} N O P E B_{i, t} \\
& +\beta_{5} N F A_{i, t}+\beta_{6} A E_{i, t}+B \text { BLAG_A } A E_{i, t}+\beta_{8} D T A_{-} S T_{i, t}+\beta_{9} D T L \_S T_{i, t} \\
& +\beta_{10} N E T \_D E F E R R E D \_L T_{i, t}+\beta_{11} D E P R \_D T L_{i, t}+e_{i, t} .
\end{aligned}
$$

PRICE is the price per share, measured three months after year end, to allow investors time to react to the tax footnote after it is released in the 10-K filing. I scale the following items by number of shares outstanding: NOA (net operating assets), $N P P E$ (net property, plant and equipment), NPENSION (net pension), NOPEB (net other post-employment retirement benefits), $N F A$ (financial assets net of debt), $A E$ (abnormal earnings, estimated as described in Appendix C), $L A G \_A E$ (lagged abnormal earnings), DTA_ST (current deferred tax assets), DTL_ST (current DTLs), NET_DEFERRED_LT (net noncurrent deferred noncurrent assets and liabilities, excluding DTLs associated with depreciation), and DEPR_DTL (the DTLs balance associated with depreciation). For ease of interpretation of the results, I code assets as positive amounts and liabilities as negative amounts. This approach results in positive expected coefficients for all balance sheet variables, both assets and liabilities.

Under ASC 740-10-30, firms must consider the realizability of their deferred tax assets, recording a valuation allowance for the portion of the assets that is not "more likely than not" to 
be realized. To test H3, whether investors' pricing of DTLs is affected by their expectations of firms' future taxable income, I exclude firm years that have net deferred tax balances of exactly zero (i.e., full valuation allowance firms). Almost all of these excluded observations involve firms with gross deferred tax assets that exceed the gross DTLs, but the net positive asset balance is fully offset with a valuation allowance. ${ }^{16}$ I exclude these firms because the reversal of DTLs in the future are unlikely to affect future cash taxes payable. My approach is similar to the Givoly and Hayn (1992) approach that considers expectations of firms' future tax circumstances when valuing DTLs. However, I implement my approach differently because the valuation allowances that I rely upon were not available under the prior accounting standard (APB 11) considered in Givoly and Hayn (1992).

To analyze my fourth hypothesis that the reversal period of DTLs is relevant for valuation, I create an additional variable, PPE_SHORT, an indicator variable equal to one if the firm is in the top quartile of shortest GAAP depreciable asset lives, and zero otherwise. I estimate a firm's GAAP asset life based on the average ratio of capital expenditures to beginning balance of net PPE over the preceding three years. ${ }^{17}$ I code firms with the shortest-lived assets as PPE_SHORT equal to one, zero otherwise. To test whether investors appear to impound depreciation-related DTLs more negatively into stock price in firms with short-lived depreciable

\footnotetext{
${ }^{16}$ There are two conditions under which a firm might have a net deferred tax asset balance of exactly zero with less than a full valuation allowance. First, the firm might have exactly zero deferred tax assets and liabilities; however, that is not possible in my study as all my observations have deferred tax liability balances for depreciation. Second, the firm might happen to have exactly equal amounts of deferred tax assets and liabilities (exclusive of the valuation allowance), to the nearest one thousand dollars. I expect these observations should be extremely rare.

${ }^{17}$ Alternatively, I could identify firms with short-lived assets based on the ratio of GAAP depreciation expense to net property and equipment. However, there are two disadvantages to using GAAP depreciation. First, depreciation is an accrual and is easier/less costly for managers to manipulate, at least compared to purchases of capital assets. Second, and more importantly, GAAP depreciation is mechanically related to DTLs; for a firm in the $40 \%$ tax bracket, every additional dollar in GAAP depreciation expense reduces the $D E P R \_D T L$ balance by 40 cents. Capital expenditures, on the other hand, are only indirectly connected with the $D E P R \_D T L$ balance via a complex interaction of the tax rate, the GAAP depreciation rate, the tax depreciation rate, over both the current and future years. Thus, I believe that the capital replacement rate better captures the construct of interest.
} 
assets, I interact PPE_SHORT with DEPR_DTL. Appendix C contains additional detail about the composition of these variables.

The model above is flexible enough to allow me to test all four hypotheses dealing with the valuation of DTLs. Consistent with $\mathrm{H} 1$, I expect a positive coefficient on DEPR_DTL, suggesting that investors recognize the economic burden associated with the depreciation-related DTLs. Consistent with $\mathrm{H} 2$, I expect that the coefficient on DEPR_DTL will remain positive even for the subset of firms with growing DEPR_DTL balances. Consistent with $\mathrm{H} 3$, I expect that the subset of firms that have full valuation allowances, and thus may not be facing the prospect of future cash taxes, to have smaller coefficients than cash-tax paying firms. Finally, consistent with H4, I expect a positive coefficient on the interaction of DEPR_DTL*PPE_SHORT, which would be consistent with investors recognizing the incremental impact on firm value from depreciation related to short-lived assets (i.e., evidence consistent with discounting).

\section{RESULTS}

\section{Investors' Recognition of Depreciation-related DTLs as Economic Burdens}

I present the results of estimating Equation (1), which tests the relation between stock prices and DTLs, in Table 3, Panels A-D. I code assets (scaled by number of shares) as positive values, whereas I code liabilities (also scaled by number of shares) as negative values. This coding causes the predicted values of each coefficient to be positive. Consistent with the prior literature, I note that across all panels of Table 3, almost all of the non-tax items have coefficients that are positive and significant. I find a positive and significant coefficient on the short-term portion of deferred tax assets, DTA_ST, consistent with the finding of Amir et al. 
(1997). This finding suggests a positive valuation of deferred tax assets expected to reverse soon (i.e., result in tax-related cash inflows in the near future).

In Table 3, Panel A, I find the coefficient on DEPR_DTL is positive and significant, consistent with investors recognizing depreciation-related DTLs as economic burdens to the firm. This result is consistent with $\mathrm{H} 1$, as the coefficient is consistent with investors pricing depreciation-related DTLs despite these liabilities being a "Tax-First" item. This result is also consistent with the theoretical predictions of Sansing (1998) and Guenther and Sansing (2000), but my result is inconsistent with the empirical results of both Amir et al. (1997) and Laux (2013). I attempt to reconcile my findings to the findings documented in prior empirical studies in Section V.

\section{Investors' Measurement of Depreciation-related DTLs}

According to the Amir et al. (1997) account growth explanation, investors price DTLs if investors can foresee these DTLs reversing (i.e., the balance of DTLs is decreasing via conversion into actual cash tax payments). Thus, in Panel B of Table 3, I limit the sample to firms with increasing levels of $D E P R \_D T L$ from year t-1 to year t. As these firms have increasing, rather than decreasing, DEPR_DTL balances, the Amir et al. (1997) explanation suggests that investors will value DTLs at near zero for this sub-group of firms. However, I find positive and significant coefficients for DEPR_DTL, consistent with $\mathrm{H} 2$. Thus, I provide evidence consistent with investors pricing depreciation-related DTLs, even for firms with growing DTLs. In untabulated analyses, I do not find a significant difference in the coefficients on DEPR_DTL in Panels A and B. Thus, consistent with H2, I do not find evidence that investors value depreciation-related DTLs differently in firms with growing DTL balances compared to all other firms. 
To test H3, I separate my sample into two groups: those firms that have full valuation allowances $($ Net DTA $=0)$ and all other firms. As previously discussed, depreciation-related DTLs signal that firms will recognize higher future taxable income relative to future GAAP income. However, I posit this higher level of taxable income will not be value relevant for firms that expect to pay no cash taxes in future years, consistent with the argument that investors recognize that these DTLs only to the extent that they affect future cash taxes payable. I note that in the left column of Table 3, Panel C, the coefficient on DEPR_DTL is not significantly different from zero for the full valuation allowance firms. However, the coefficient on $D E P R \_D T L$ for the non-valuation allowance firms in the right column is positive and significant, suggesting that investors impound the future economic burden of these DTLs into stock prices. These two results are consistent with my prediction for $\mathrm{H} 3$ that investors' pricing of DTLs is affected by their expectations of future taxable income. In untabulated analyses, I find that the coefficients for DEPR_DTL in the two columns are statistically different from each other at the $\mathrm{p}<0.05$ level. This result highlights the benefit of my new measure of firm-level tax sensitivity in distinguishing the valuation impact of firms' valuation allowances. ${ }^{18}$

$\mathrm{H} 4$ predicts that investor pricing of DTLs is affected by expected reversal period of the temporary difference. This is because firms with shorter-lived depreciable assets face the economic burden of depreciation-related DTLs sooner than firms with longer-lived depreciable assets. Thus, firms with shorter-lived assets should face higher future tax burdens, on a net present value basis, compared to identical firms that have longer-lived assets. To test this hypothesis, I examine whether investors differentially value the depreciation-related DTLs in firms with shorter-lived assets, using the interaction of PPE_SHORT and DEPR_DTL.

\footnotetext{
${ }^{18}$ This approach to valuation allowances also appears in Finley et al. (2017).
} 
I note that in the first column of Panel D of Table 3, which includes all observations, the coefficient on the interaction variable is positive, but insignificant. However, in the second column, which eliminates the full valuation allowance firms, the coefficient on the interaction variable is positive and marginally significant. This result provides some evidence that investors discount depreciation-related DTLs based on the expected reversal time periods, at least for taxsensitive firms.

One potential concern with the analyses in this section is that depreciation-related DTLs contain value-relevant non-tax information and this non-tax information content is driving the observed relation with price. For example, Thomas and Zhang (2014) find that tax balances contain information regarding future profitability, which would be associated with current share price. While I include both current-year abnormal earnings and lagged abnormal earnings in Equation (1), in untabulated analysis I supplement the model to include following-year abnormal earnings, computed on an ex-post basis. I find that the positive and statistically-significant coefficients on the variables of interest (i.e., DEPR_DTL and the interaction term) remain positive and statistically significant in each of the analyses presented in the panels of Table 3 . Thus, I conclude that my primary results are robust to the inclusion of future profitability.

\section{SUPPLEMENTAL ANALYSES}

In this section, I perform five additional analyses. First, I employ an alternative methodology to measure investor pricing of depreciation-related DTLs. Second, I provide an additional demonstration of the utility of excluding tax-insensitive, full valuation allowance firms. Third, to facilitate comparison of my findings to those of prior empirical research, I attempt to quantify the effect of my larger sample size and inclusion of bonus depreciation on my 
results. Fourth, I examine the generalizability of my results, based on my sample selection process. Finally, I reexamine H2, H3 and H4 using a single, comprehensive model, rather than separate cross-sections of data.

\section{Alternative Valuation of Depreciation-related DTLs}

Graham, Raedy, and Shackelford (2012) call for other approaches to examine investors' valuation of DTLs, beyond the price-level approach. Thus, I also consider a changes-based methodology, based on Faulkender and Wang (2006) (hereafter, "FW"). The FW model values firm cash holdings by regressing changes in market value of equity (in excess of the relevant performance benchmark) on a firm's change in cash and related items. ${ }^{19}$ As each variable (on both sides of the equation) is scaled by lagged market value of equity, the coefficients of the changes variables in the FW regression can be interpreted as the market value of an incremental dollar of each asset in the model. I add variables associated with depreciation-related deferred taxes to their model. Thus, my model is:

$$
\begin{aligned}
& \text { Excess_Return }_{i, t}=\alpha_{1} \Delta C A S H_{i, t}+\alpha_{2} \Delta D T L \_D E P R_{i, t}+\alpha_{3} D T L \_D E P R_{i, t-1} \\
& \quad+\alpha_{4} \Delta P P E_{i, t}+\alpha_{5} \Delta E_{i, t}+\alpha_{6} \Delta N A_{i, t}+\alpha_{7} \Delta R D_{i, t}+\alpha_{8} \Delta I_{i, t}+\alpha_{9} \Delta D I V_{i, t} \\
& \quad+\alpha_{10} C_{A S H} H_{i t-1}+\alpha_{12} L E V_{i, t}+\alpha_{13} N F_{i, t}+e_{i, t} .
\end{aligned}
$$

For this test, I scale all variables (except leverage, $L E V$ ) by lagged market value of equity. Excess_Return is the stock's actual return in excess of a benchmark return formed from $5 \times 5$ Fama-French size and book-to-market portfolios. All change variables are measured as the change from year t-1 to year t. $\triangle C A S H$ is the change in cash, $\triangle P P E$ is the change in net property plant and equipment, $\Delta E$ is the change in earnings, while $\triangle N A$ is the change in total assets (other than cash). $\Delta R D$ is the change in $\mathrm{R} \& \mathrm{D}$ spending, and $\Delta I$ is the change in interest expense. $\Delta D I V$

\footnotetext{
${ }^{19}$ As FW note, the independent variables should technically be the unexpected changes in values. However, they find that using actual changes, rather than unexpected changes, works well in their model. I employ the same approach with respect to the tax items I add to the model. I expect that changes in tax items would be equally difficult for investors to forecast as changes in cash items.
} 
is the change in dividends paid, and $C A S H$ is the lagged level of cash. $L E V$ is the market-based leverage, and $N F$ is the total of net equity and net debt financing obtained during the year. Variables of interest are $\triangle D T L \_D E P R$ and $D T L \_D E P R$, which are the change in and lagged level of the depreciation-related DTLs, respectively. DTL_DEPR is expressed as a positive number (even though it is a liability balance); thus, a positive value of $\triangle D T L \_D E P R$ corresponds with a growing depreciation-related DTL balance. Following FW, I truncate values at the 1 and 99 percent levels for all years combined. See Appendix C for more detailed definitions of each variable. For this analysis, I limit my analysis to industrial firms (SICs 2000-4000).

I present the results of estimating Equation (2) in Table 4. In Column A, I exclude fixed effects (similar to FW), while in Column B, I add industry and year fixed effects. Overall, the results are consistent with the results of my primary tests in Table 3. I note that the coefficient on $\triangle D T L_{-} D E P R$ is negative and significant in both specifications, consistent with investors viewing depreciation-related DTLs as economic burdens to firms. This result supports the predictions of Sansing (1998), Guenther and Sansing (2000), and Guenther and Sansing (2004). I also note that the coefficient on the level of DTL_DEPR is positive and significant in both specifications, suggesting that firms that have larger levels of tax deferral associated with depreciation have larger excess returns. This result lends support to the notion that depreciation-related DTLs function as interest-free loans from the government. ${ }^{20}$

\footnotetext{
${ }^{20}$ Consider two firms, Firm A and Firm B, that are identical except that Firm A receives a $\$ 100$ million interest-free loan from the government, payable in one year. While this liability is an economic obligation, the shareholders of Firm A will benefit, relative to shareholders of Firm B, because Firm A can deploy the proceeds of the loan due to the obvious arbitrage opportunity associated with receiving zero-cost capital. At the end of the one-year period, the interest-free loan is repaid, and Firm A has higher net assets than Firm B, due to the profits derived from investing the loan proceeds. The stock returns of Firm A should reflect this favorable arbitrage opportunity.
} 


\section{Using Net Zero Deferred Taxes to Determine the Tax Sensitivity of Firms}

An innovation I introduce in this paper is removing firm-year observations containing large valuation allowances in order to focus my analyses on the cross-section of firms that are the most tax sensitive. Mechanically, I eliminate observations that have a net deferred tax balance (i.e., all deferred tax assets less all DTLs) of exactly zero, expecting that the net deferred tax assets are fully offset by valuation allowances, suggesting that the firm is unlikely to pay cash taxes in the near future. Leaving those observations in the analysis can bias results of tax analyses toward zero, since these firms are not tax sensitive.

To validate my assumption that these full valuation allowance firms are tax-insensitive, I use the following model adapted from Laux (2013), which regresses future cash taxes paid on current-year profitability and depreciation-related DTL measures:

$$
\begin{aligned}
& \text { TXPD }_{i, t+n}=\alpha_{0}+\alpha_{1} P T R O A_{i, t}+\alpha_{2} D T L \_D E P R \_A T_{i, t} \\
& \quad+\alpha_{3} D T L \_D E P R \_A T_{i, t} * N O \_P P E \_G R O W T H_{i, t} \\
& \quad+\alpha_{4} N O \_P P E \_G R O W T H_{i, t}+\alpha_{k} C O N T R O L S+e_{i, t} .
\end{aligned}
$$

TXPD is cash taxes paid scaled by total assets, PTROA is pretax return on assets, $D T L \_D E P R \_A T$ is the balance of depreciation-related DTLs scaled by total assets, and $N O \_P P E \_G R O W T H$ is an indicator variable set equal to one if gross property, plant and equipment is higher in year $\mathrm{t}-1$ than in year $\mathrm{t}$, and zero otherwise. I winsorize all continuous variables at 1 and 99 percent each year. I test Equation (3) on two distinct samples: first on a sample of firms excluding those observations with a full valuation allowance and then on the full sample which includes firms with a full valuation allowance. I expect the depreciation-related DTLs for growing firms will continue to increase and expect all other firms will be associated with declining depreciation-related DTLs. Thus, I predict that growing firms with depreciationrelated tax deferral in year $\mathrm{t}$ will further increase their tax deferral in future years, decreasing 
their future cash taxes paid. Accordingly, I expect a negative coefficient on DTL_DEPR_AT and I expect a positive coefficient on the interaction term, suggesting that non-growing firms are unable to achieve the same future tax deferral.

In Panel A of Table 5, I present the results of testing Equation (3) on the set of firms that excludes firms with full valuation allowances. For growing firms, I find a negative and significant relation between the net depreciation-related DTLs in year $\mathrm{t}\left(D T L \_D E P R \_A T\right)$ and the cash taxes paid in years $t+1$ through year $t+4$. This finding suggests that growing firms not only avoid the reversal of depreciation-related tax deferral, but they also increase their tax deferral in future years, reducing future tax payments. On the other hand, the coefficient on the interaction term $D T L \_D E P R \_A T^{*} N O \_P P E \_G R O W T H$ is positive and significant, suggesting that non-growing firms cannot expect the same incremental future tax deferral and incur incremental future tax payments.

In Panel B of Table 5, I repeat the same analysis; however, I now consider all firms, including those observations with full valuation allowances. The addition of these full valuation allowance firms arguably biases the coefficients of interest (i.e., $D T L \_D E P R \_A T$ and $\left.D T L \_D E P R \_A T * N O \_P P E \_G R O W T H\right)$ toward zero as I expect the full valuation allowance firms will pay little in the way of future cash taxes. Consistent with my expectations, I note insignificant coefficients on my variables of interest, suggesting that including the valuation allowance firms affects the tests of future tax payments and inferences from the analysis. This specification illustrates the importance of considering firm-level expectations of future cash tax payments when measuring the value of DTLs. 


\section{Comparison with Prior Empirical Research}

Consistent with the prior analytical work that suggests depreciation-related DTLs are value relevant, I find evidence of a negative relation between stock prices and these DTLs. However, my findings conflict with prior empirical studies that report valuation coefficients near zero or insignificant (Amir et al. 1997; Laux 2013). I offer three key differences between the methodologies of my study and those prior empirical studies as potential explanations for the difference in results. ${ }^{21}$

First, because I do not depend on hand collection, I employ a much larger data set than the prior studies. Amir et al. (1997), for example, include 1,114 observations, while Laux (2013) includes 2,748 observations. In contrast, my study involves a substantially larger sample that potentially increases the statistical power of the tests I perform to find the hypothesized relations, assuming that these relations are present.

Second, for almost all the years in my study, bonus depreciation was in effect in the tax law, increasing the magnitude of depreciation-related DTLs. Larger values of depreciation decrease the likelihood of finding a null result, assuming the hypothesized association is present. Bonus depreciation was not in effect during the period studied by Amir et al. (1997) and it was in effect for only three of the 14 years of the Laux (2013) study.

In an attempt to quantify the implications of my study employing a larger data set and including years involving bonus depreciation, I re-estimate Equation (1) on a sample limited to S\&P 500 firms, similar to both Amir et al. (1997) and Laux (2013). I then partition my sample into two sub-samples based on an estimate of the expected level of tax benefit that bonus

\footnotetext{
${ }^{21}$ Because of the data formatting requirements of my Perl script (i.e., HTML), I cannot directly test my approach on the period covered by the prior empirical studies as the script is ineffective for $10-\mathrm{K}$ filings prior to 2005 .
} 
depreciation could provide to firms. I proxy for the expected benefit of bonus depreciation based on a median split of GAAP replacement rates. ${ }^{22}$ For those firms that receive relatively little benefit from bonus depreciation, I expect my results to be consistent with the results of prior research. For firms that had relatively larger benefits from bonus depreciation, I expect my results will diverge from prior research.

In Table 6, I present the results of this analysis. In the left-hand column, I note an insignificant coefficient on DEPR_DTL in the sample of S\&P 500 firms that benefit less from bonus depreciation. This null result is consistent with prior empirical results on a smaller sample of similar-sized firms with less benefit from bonus depreciation. However, in the right-hand column of Table 6 , the sample of firms that benefit the most from bonus tax depreciation, I note a positive and significant coefficient on depreciation-related DTLs, consistent with the results presented in my study. Taken together, these two results suggest that, at least with respect to S\&P 500 firms, one difference between my results and the results of prior empirical research is the effect of bonus depreciation.

In addition to the bonus depreciation effect, for some of my analyses, I employ a novel approach that excludes firm-year observations with a net deferred tax asset of exactly zero (i.e., excluding full valuation allowance firm years). I exclude these firms because investors are likely to assess a much lower (perhaps zero) value of the DTLs of these firms because they are expected to pay virtually no future cash taxes. Including these zero deferred tax firms would bias my $D E P R \_D T L$ coefficient toward zero, a result that is evident in Table 3, Panel C.

\footnotetext{
${ }^{22}$ For example, a firm that has a large amount of over-the-road tractor/truck equipment (with a tax depreciation life of three years) will benefit less from the enactment of bonus depreciation than a firm with a large amount of water transportation equipment (with a tax depreciation life of ten years).
} 


\section{Data Sample and Generalizability}

The Perl scripts I employ collect depreciation-related DTL amounts for 8,898 of the possible 26,017 firm years that meet my data requirements identified in Table 1 . In Panel B of Table 2, I note that the 17,119 firms in the non-Perl sample are larger in size and lower in profitability (proxied by $A E$ ). To test whether firm size or profitability affect my results, I repeat my primary tests (Table 3, Panels A-D), using either the top three quartiles of size or the bottom three quartiles of ROA in the Perl data set. My results are qualitatively unchanged (untabulated). Thus, I do not anticipate differences in samples affect the generalizability of my results.

\section{Single, Comprehensive Model}

In addition to the cross-sectional analyses performed above to test $\mathrm{H} 2$ (growth firms) and H3 (future income firms), I develop a single, comprehensive model that that allows the simultaneous testing of all hypotheses. I create an additional indicator variable GROWTH which I set equal to one if the firm has growth in $D E P R \_D T L$ between year t-1 to year $\mathrm{t}$ (consistent with the primary testing of $\mathrm{H} 2$, above), zero otherwise. I then expand Equation 1 by adding the interaction of $D E P R \_D T L$ with each possible combination of $G R O W T H, Z E R O \_D T A$, and PPE_SHORT (i.e., a quadruple interaction).

In untabulated analyses, I find results that are generally consistent with the outcomes reported in Table 3, although the overall incremental effect of PPE_SHORT is no longer significant at conventional levels in this comprehensive model. However, for non-growing firms with expected future income, the incremental effect of PPE_SHORT is positive and strongly significant $(\mathrm{p}<0.001)$. This result is consistent with my hypotheses, since it suggests that investors ascribe lower value to firms that have DTLs that will reverse in the near future that will result in cash tax payments. 
I note that in this comprehensive model, the VIF scores of the interaction terms range from 10 to 30, while the VIF scores on the variables of interest in the main tests above are all less than 5. Thus, while this fully interacted model produces results that are generally consistent with my conclusions above, I caution readers that this comprehensive model is subject to multicollinearity concerns beyond what exist in the primary testing approach.

\section{CONCLUSION}

In this study, I examine competing explanations concerning investor valuation of depreciation-related DTLs. I predict and find that investors recognize depreciation-related DTLs as economic burdens. This finding provides the first empirical evidence that is consistent with prior analytical research but conflicts with prior empirical work. I also examine the factors that investors consider when measuring depreciation-related DTLs. First, I present evidence consistent with investors pricing DTLs even when the balance of DTLs is growing (due to growth in depreciable assets). Second, I find evidence suggesting investors appear to perceive a lower economic burden for depreciation-related DTLs of firms with a lower likelihood of paying future cash taxes. Finally, I find some evidence that investors appear to consider the expected reversal period of accelerated tax depreciation temporary differences when measuring the value of depreciation-related DTLs. I supplement these results with an alternative calculation using the model from Faulkender and Wang (2006) to measure investors' valuation of DTLs and find similar results. My study also introduces to the literature a new approach for identifying taxinsensitive firms. This new measure may be useful to future researchers in the study of loss firms. 


\section{TABLE 1}

\section{Sample Selection}

Firm years available in Compustat, 2005-2014

111,814

Less firms with less than 10 million shares outstanding

$(33,501)$

78,313

Less firms not traded on major exchanges

$(31,105)$

47,208

Less firms with share prices less than $\$ 1$

43,861

Less Utilities, Financial and REIT firms (SICs 4900-4999, SIC

6000-6099 and SIC 6798)

33,528

Less firms with missing information to compute abnormal

earnings and other control variables

Subtotal--Available Compustat Firms

26,017

Less firm years for which no deferred tax liability for

depreciation was found using Perl script (see Appendix III)

$(17,119)$

Total observations for initial test (Table 3, Panel A)

8,898 
TABLE 2

Panel A: Descriptive Statistics

\begin{tabular}{lrrrrrr}
\hline Variable & N & Mean & Std Dev & P25 & Median & P75 \\
\hline PRICE & 8,898 & 30.32 & 29.35 & 9.51 & 22.42 & 41.71 \\
NOA & 8,898 & 7.66 & 12.78 & 0.23 & 3.42 & 10.99 \\
NPPE & 8,898 & 8.08 & 13.06 & 0.82 & 2.98 & 8.85 \\
NPENSION & 8,898 & -0.36 & 1.11 & -0.05 & 0.00 & 0.00 \\
NOPEB & 8,898 & -0.17 & 0.63 & 0.00 & 0.00 & 0.00 \\
NFA & 8,898 & -3.12 & 11.54 & -6.45 & -0.23 & 2.67 \\
AE & 8,898 & -0.13 & 2.26 & -0.77 & 0.00 & 0.84 \\
LAG_AE & 8,898 & -0.10 & 2.19 & -0.72 & 0.02 & 0.82 \\
DTA_ST & 8,898 & 0.29 & 0.41 & 0.00 & 0.15 & 0.39 \\
DTL_ST & 8,898 & -0.02 & 0.10 & 0.00 & 0.00 & 0.00 \\
NET_DEFERRED_LT & 8,898 & -0.78 & 2.65 & -0.90 & -0.03 & 0.20 \\
DEPR_DTL & 8,898 & -1.13 & 2.54 & -0.90 & -0.22 & -0.05 \\
PPE_SHORT & 8,898 & 0.25 & 0.43 & 0.00 & 0.00 & 0.00
\end{tabular}

PRICE is the price per share, three months after year end. The following items are scaled by number of shares outstanding: NOA (net operating assets), NPPE (net property, plant and equipment), NPENSION (net pension), NOPEB (net other post-employment retirement benefits), NFA (financial assets net of debt), $A E$ (abnormal earnings, estimated as described in Appendix III), $L A G \_A E$ (lagged abnormal earnings), DTA_ST (current deferred tax assets), DTL_ST (current deferred tax liabilities), NET_DEFERRED_LT (net noncurrent deferred tax liabilities, except for deferred tax liabilities associated with depreciation), DEPR_DTL (the deferred tax liability balance associated with depreciation).

PPE_Short identifies firms in the top quartile of 3-year average PPE replenishment rate (CAPX scaled by lagged net PPE). These firms have capital assets with the shortest economic lives and therefore will require the most rapid capital asset replacement. All balance sheet variables are entered as positive or negative values, as appropriate (e.g., NPENSION is entered as a negative value, since it is a liability). See Appendix III for all variable definitions. 
TABLE 2

Panel B: Descriptive Statistics

Means of Perl Data Set and Compustat Data Set

\begin{tabular}{|c|c|c|c|c|}
\hline Variable & $\begin{array}{c}\text { Perl } \\
\text { Data }\end{array}$ & $\begin{array}{r}\text { Non-Perl } \\
\text { Data }\end{array}$ & Diff. & $\begin{array}{l}\text { p-value } \\
\text { of t-test }\end{array}$ \\
\hline PRICE & 30.32 & 26.72 & 3.60 & 0.001 \\
\hline$N O A$ & 7.66 & 6.61 & 1.05 & 0.001 \\
\hline NPPE & 8.08 & 8.14 & -0.06 & 0.816 \\
\hline NPENSION & -0.36 & -0.35 & -0.01 & 0.331 \\
\hline NOPEB & -0.17 & -0.17 & 0.00 & 0.393 \\
\hline$N F A$ & -3.12 & -3.06 & -0.06 & 0.823 \\
\hline$A E$ & -0.13 & -0.14 & 0.01 & 0.039 \\
\hline$L A G \_A E$ & -0.10 & -0.10 & 0.00 & 0.149 \\
\hline$D T A \_S T$ & 0.29 & 0.21 & 0.08 & 0.001 \\
\hline$D T L \_S T$ & -0.02 & -0.02 & 0.00 & 0.001 \\
\hline SIZE & 6.90 & 7.03 & -0.13 & 0.001 \\
\hline
\end{tabular}

Observations $\quad 8,898 \quad 17,119$

This table compares the mean values of data present in the Perl-collected data set to the mean values of firms in the Compustat data set that were not selected by the Perl program. The formation of the Compustat data set is shown on Table 1, Panel A.

PRICE is the price per share, three months after year end. The following items are scaled by number of shares outstanding: NOA (net operating assets), NPPE (net property, plant and equipment), NPENSION (net pension), $N O P E B$ (net other post-employment retirement benefits), $N F A$ (financial assets net of debt), $A E$ (abnormal earnings, estimated as described in Appendix III), LAG_AE (lagged abnormal earnings), DTA_ST (current deferred tax assets), DTL_ST (current deferred tax liabilities). SIZE is computed as the log of total assets. 
TABLE 2

Panel C: Correlation Matrix

\begin{tabular}{|c|c|c|c|c|c|c|c|c|c|c|c|c|c|}
\hline & & (1) & (2) & (3) & (4) & (5) & (6) & (7) & (8) & (9) & (10) & (11) & $(12)$ \\
\hline PRICE & (1) & & & & & & & & & & & & \\
\hline$N O A$ & (2) & 0.34 & & & & & & & & & & & \\
\hline NPPE & (3) & 0.34 & 0.07 & & & & & & & & & & \\
\hline NPENSION & (4) & -0.18 & -0.24 & -0.20 & & & & & & & & & \\
\hline NOPEB & (5) & -0.15 & -0.16 & -0.27 & 0.61 & & & & & & & & \\
\hline$N F A$ & (6) & -0.14 & -0.56 & -0.57 & 0.17 & 0.17 & & & & & & & \\
\hline$A E$ & (7) & 0.30 & -0.18 & -0.24 & -0.02 & -0.01 & 0.39 & & & & & & \\
\hline$L A G \_A E$ & (8) & 0.26 & -0.13 & -0.18 & -0.03 & -0.02 & 0.33 & 0.57 & & & & & \\
\hline$D T A \_S T$ & (9) & 0.38 & 0.30 & 0.16 & -0.35 & -0.29 & -0.14 & 0.13 & 0.15 & & & & \\
\hline$D T L \_S T$ & (10) & -0.15 & -0.10 & -0.21 & 0.10 & 0.07 & 0.12 & 0.00 & 0.00 & 0.01 & & & \\
\hline NET_DEFERRED_LT & (11) & -0.30 & -0.35 & -0.62 & 0.01 & 0.08 & 0.45 & 0.25 & 0.22 & -0.05 & 0.11 & & \\
\hline$D E P R \_D T L$ & (12) & -0.24 & -0.10 & -0.74 & 0.16 & 0.25 & 0.40 & 0.20 & 0.16 & -0.11 & 0.14 & 0.69 & \\
\hline PPE_SHORT & (13) & -0.05 & -0.13 & -0.21 & 0.17 & 0.14 & 0.19 & 0.09 & 0.10 & -0.15 & 0.06 & 0.12 & 0.15 \\
\hline
\end{tabular}

This table presents Pearson correlations among the variables used in this study. Correlations in bold are statistically significant at the 10 percent level or lower. PRICE is the price per share, three months after year end. The following items are scaled by number of shares outstanding: NOA (net operating assets), NPPE (net property, plant and equipment), NPENSION (net pension), NOPEB (net other post-employment retirement benefits), NFA (financial assets net of debt), $A E$ (abnormal earnings, estimated as described in Appendix III), $L A G \_A E$ (lagged abnormal earnings), DTA_ST (current deferred tax assets), DTL_ST (current deferred tax liabilities), NET_DEFERRED_LT (net noncurrent deferred tax liabilities, except for deferred tax liabilities associated with depreciation), $D E P R \_D T L$ (the deferred tax liability balance associated with depreciation).

PPE_Short identifies firms in the top quartile of 3-year average PPE replenishment rate (CAPX scaled by lagged net PPE). These firms have capital assets with the shortest economic lives and therefore will require the most rapid capital asset replacement. All balance sheet variables are entered as positive or negative values, as appropriate (e.g., NPENSION is entered as a negative value, since it is a liability). See Appendix III for all variable definitions. 
TABLE 3

Market Valuation of Deferred Tax Balance Sheet Components

\begin{tabular}{lcc}
\multicolumn{2}{c}{ Panel A, H1: Recognition Hypothesis } \\
Coefficient \\
DV $=$ (t-stat)
\end{tabular}


TABLE 3

Market Valuation of Deferred Tax Balance Sheet

Components

Panel B, H2: Measurement-Account Growth

\begin{tabular}{|c|c|c|}
\hline$D V=P R I C E$ & Prediction & $\begin{array}{c}\text { Increasing } \\
\text { DEPR_DTL } \\
\text { Firms Only } \\
\text { Coefficient } \\
\text { (t-stat) }\end{array}$ \\
\hline Intercept & $(+)$ & $\begin{array}{l}(0.91) \\
(0.10)\end{array}$ \\
\hline$N O A$ & $(+)$ & $\begin{array}{l}1.27 \text { *** } \\
(11.62)\end{array}$ \\
\hline NPPE & $(+)$ & $\begin{array}{c}1.51 \text { *** } \\
(10.76)\end{array}$ \\
\hline NPENSION & $(+)$ & $\begin{array}{c}0.74 \\
(1.21)\end{array}$ \\
\hline NOPEB & $(+)$ & $\begin{array}{l}3.41 \text { *** } \\
(2.70)\end{array}$ \\
\hline$N F A$ & $(+)$ & $\begin{array}{l}0.93 * * * \\
(6.28)\end{array}$ \\
\hline$A E$ & $(+)$ & $\begin{array}{l}3.88 \quad * * * \\
(10.68)\end{array}$ \\
\hline$L A G \_A E$ & $(+)$ & $\begin{array}{l}2.15 \text { *** } \\
(6.49)\end{array}$ \\
\hline$D T A \_S T$ & $(+)$ & $\begin{array}{l}9.16 * * * \\
(4.22)\end{array}$ \\
\hline$D T L \_S T$ & $(+)$ & $\begin{array}{l}-1.59 \\
(0.20)\end{array}$ \\
\hline NET_DEFERRED_LT & $(+)$ & $\begin{array}{r}0.05 \\
(0.10)\end{array}$ \\
\hline$D E P R \_D T L$ & $(+)$ & $\begin{array}{l}\mathbf{0 . 8 8} * * \\
(\mathbf{2 . 5 1})\end{array}$ \\
\hline $\begin{array}{l}\text { Observations } \\
\text { Fixed Effects } \\
\text { Clustered S.E. } \\
\text { R-squared }\end{array}$ & & $\begin{array}{r}3,640 \\
\text { Ind/Yr } \\
\text { Firm } \\
0.5791 \\
\end{array}$ \\
\hline
\end{tabular}




\section{TABLE 3}

\section{Market Valuation of Deferred Tax Balance Sheet Components}

\section{Panel C, H3: Measurement-Future Income}

\begin{tabular}{|c|c|c|c|}
\hline$D V=P R I C E$ & Prediction & $\begin{array}{c}\text { Net DTA = } 0 \\
\text { Coefficient } \\
\text { (t-stat) }\end{array}$ & $\begin{array}{c}\text { Net DTA Not } 0 \\
\text { Coefficient } \\
\text { (t-stat) }\end{array}$ \\
\hline Intercept & $(+)$ & $\begin{array}{l}16.43^{* * * *} \\
(3.10)\end{array}$ & $\begin{array}{l}15.93 \\
(1.24)\end{array}$ \\
\hline$N O A$ & $(+)$ & $\begin{array}{l}1.40 * * * \\
(4.68)\end{array}$ & $\begin{array}{l}1.15 \text { *** } \\
(13.98)\end{array}$ \\
\hline NPPE & $(+)$ & $\begin{array}{l}2.09 * * * \\
(3.99)\end{array}$ & $\begin{array}{l}1.44 * * * \\
(12.54)\end{array}$ \\
\hline NPENSION & $(+)$ & $\begin{array}{c}3.53 \\
(1.47)\end{array}$ & $\begin{array}{c}0.21 \\
(0.44)\end{array}$ \\
\hline NOPEB & $(+)$ & $\begin{array}{c}2.38 \\
(0.69)\end{array}$ & $\begin{array}{l}2.83 * * * \\
(3.56)\end{array}$ \\
\hline$N F A$ & $(+)$ & $\begin{array}{l}2.14 * * * \\
(3.73)\end{array}$ & $\begin{array}{l}0.78 \text { *** } \\
(6.59)\end{array}$ \\
\hline$A E$ & $(+)$ & $\begin{array}{c}0.72 \\
(1.03)\end{array}$ & $\begin{array}{l}4.03 \text { *** } \\
(16.02)\end{array}$ \\
\hline$L A G \_A E$ & $(+)$ & $\begin{array}{l}0.62 * \\
(1.78)\end{array}$ & $\begin{array}{l}2.03 * * * \\
(9.45)\end{array}$ \\
\hline$D T A \_S T$ & $(+)$ & $\begin{array}{l}24.03 \\
(0.52)\end{array}$ & $\begin{array}{l}10.09 * * * \\
(6.35)\end{array}$ \\
\hline$D T L \_S T$ & $(+)$ & $\begin{array}{l}70.30 \\
(1.20)\end{array}$ & $\begin{array}{l}-5.15 \\
(0.88)\end{array}$ \\
\hline NET_DEFERRED_LT & $(+)$ & $\begin{array}{l}22.08 \\
(0.49)\end{array}$ & $\begin{array}{l}-0.60 \\
(1.61)\end{array}$ \\
\hline$D E P R \_D T L$ & $(+)$ & $\begin{array}{c}0.13 \\
(1.34)\end{array}$ & $\begin{array}{l}1.33 * * * \\
(2.88)\end{array}$ \\
\hline Observations & & 745 & 8,153 \\
\hline Fixed Effects & & Ind/Yr & Ind/Yr \\
\hline Clustered S.E. & & Firm & Firm \\
\hline R-squared & & 0.3434 & 0.5632 \\
\hline
\end{tabular}


TABLE 3

Market Valuation of Deferred Tax Balance Sheet Components

\section{Panel D, H4: Measurement—Discounting}

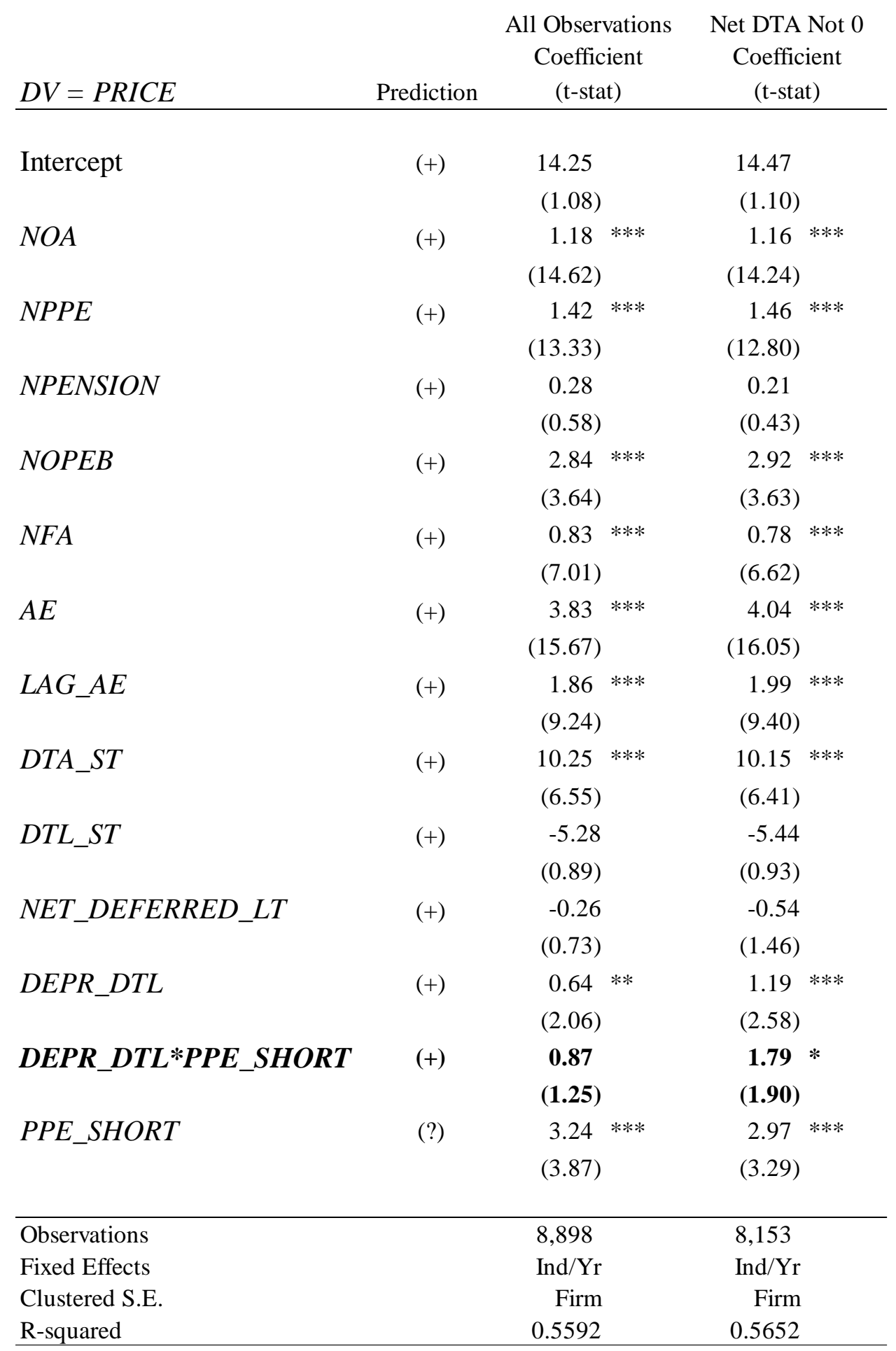


Table 3, Panels A-D, report the results of estimating equation (1) regressing price per share, three months after fiscal year end, on balance sheet items and abnormal earnings. All independent variables, other than the indicator variable PPE_SHORT, are expressed on a per-share basis. Panel A, which tests H1, includes all observations listed in Table 1. Panel B, which tests H2, is limited to those firms where the absolute value of depreciation-related deferred tax liabilities is increasing. Panel $\mathrm{C}$, which tests $\mathrm{H} 3$, splits the full set of observations from Table 1 into those with full valuation allowance accounts and those without full valuation allowance accounts. Panel D, which tests $\mathrm{H} 4$, includes both the full set of observations in the left column and the set of observations without full valuation allowances in the right column.

The following items are scaled by number of shares outstanding: NOA (net operating assets), NPPE (net property, plant and equipment), NPENSION (net pension),

$N O P E B$ (net other post-employment retirement benefits), $N F A$ (financial assets net of debt), $A E$ (abnormal earnings, estimated as described in Appendix III), $L A G \_A E$ (lagged abnormal earnings), DTA_ST (current deferred tax assets), DTL_ST (current deferred tax liabilities), NET_DEFERRED_LT (net noncurrent deferred tax liabilities, except for deferred tax liabilities associated with depreciation), DEPR_DTL (the deferred tax liability balance associated with depreciation).

PPE_Short identifies firms in the top quartile of three-year average PPE replenishment rate (CAPX scaled by lagged net PPE). These firms have capital assets with the shortest economic lives and therefore will require the most rapid capital asset replacement. All balance sheet variables are entered as positive or negative values, as appropriate (e.g., NPENSION is entered as a negative value, since it is a liability).

Thus, predicted signs for all continuous variables are positive, and the interaction term is predicted to be positive. See Appendix III for all variable definitions. *, **, and *** denote economic significance at the 10,5 , and $1 \%$ levels, respectively. 
TABLE 4

Supplemental Analysis

Market Valuation of Deferred Tax Liabilities

\begin{tabular}{|c|c|c|c|}
\hline $\mathrm{DV}=$ Excess Return & Prediction & $\begin{array}{c}\text { No F.E. } \\
\text { Coefficient } \\
\text { (t-stat) }\end{array}$ & $\begin{array}{c}\text { With F.E. } \\
\text { Coefficient } \\
\text { (t-stat) }\end{array}$ \\
\hline Intercept & (?) & $\begin{array}{r}-0.01 \\
(1.02)\end{array}$ & $\begin{array}{l}-0.10 * \\
(1.90)\end{array}$ \\
\hline$\triangle C A S H$ & $(+)$ & $\begin{array}{l}1.14^{* * *} \\
(11.02)\end{array}$ & $\begin{array}{l}1.20^{* * *} \\
(11.43)^{*}\end{array}$ \\
\hline$\triangle D T L \_D E P R$ & $(-)$ & $\begin{array}{l}-1.24 * * \\
(1.96)\end{array}$ & $\begin{array}{c}-1.11 * \\
(1.75)\end{array}$ \\
\hline$D T L \_D E P R_{t-1}$ & $(+)$ & $\begin{array}{l}0.86 \text { *** } \\
(5.82)\end{array}$ & $\begin{array}{l}0.98 \text { *** } \\
(5.66)\end{array}$ \\
\hline$\triangle P P E$ & (?) & $\begin{array}{r}0.13 \\
(0.75)\end{array}$ & $\begin{array}{r}0.09 \\
(0.53)\end{array}$ \\
\hline$\Delta E$ & $(+)$ & $\begin{array}{l}0.68^{* * * *} \\
(7.52)\end{array}$ & $\begin{array}{l}0.68^{* * *} \\
(7.45)\end{array}$ \\
\hline$\triangle N A$ & $(+)$ & $\begin{array}{l}0.47^{* * *} \\
(6.81)\end{array}$ & $\begin{array}{l}0.49 * * * \\
(7.04)\end{array}$ \\
\hline$\triangle R D$ & $(+)$ & $\begin{array}{l}1.18^{* *} \\
(1.98)\end{array}$ & $\begin{array}{l}1.25^{* *} \\
(2.07)\end{array}$ \\
\hline$\Delta I$ & $(-)$ & $\begin{array}{l}-1.55 * \\
(1.67)\end{array}$ & $\begin{array}{r}-1.57 \\
(1.62)\end{array}$ \\
\hline$\triangle D I V$ & $(+)$ & $\begin{array}{l}3.80 * * * \\
(3.47)\end{array}$ & $\begin{array}{l}3.85^{* * *} \\
(3.61)\end{array}$ \\
\hline$C A S H_{t-1}$ & $(+)$ & $\begin{array}{l}0.19^{* * * *} \\
(3.85)\end{array}$ & $\begin{array}{l}0.29 * * * \\
(5.55)\end{array}$ \\
\hline$L E V$ & $(-)$ & $\begin{array}{l}-0.37^{* * *} \\
(7.24)\end{array}$ & $\begin{array}{l}-0.45^{* * *} \\
(8.31)\end{array}$ \\
\hline$N F$ & $(+)$ & $\begin{array}{l}-0.38 * * * \\
(4.07)\end{array}$ & $\begin{array}{l}-0.36 * * * \\
(3.89)\end{array}$ \\
\hline Observations & & 3,555 & 3,555 \\
\hline Fixed Effects & & None & Ind/Yr \\
\hline Clustered S.E. & & Firm & Firm \\
\hline R-squared & & 0.1886 & 0.2106 \\
\hline
\end{tabular}


This table shows the effects of regressing excess returns (see Appendix III) on certain firm characteristics. All firms in this analysis have SIC codes between 2000 and 4000, inclusive. All of the dependent variables (except $L E V$ ) are deflated by lagged market value of equity, so the coefficients of change variables can be interpreted as the marginal value of a dollar of that item. This approach is identical to Faulkender and Wang (2006), except that this regression also includes $\triangle D T L \_D E P R, D T L \_D E P R$ and $\triangle P P E$. Column A does not include fixed effects, while Column B does include fixed effects for industry and year.

$\triangle C A S H$ is change in cash from year t-1 to year t. Variables of interest are $\triangle D T L \_D E P R$ and $D T L \_D E P R$, which are the change in and lagged balance of the deferred tax liability associated with depreciation. $D T L \_D E P R$ is expressed as a positive number (even though it is a liability balance), so a positive $\triangle D T L_{-} D E P R$ corresponds with a growing depreciationrelated deferred tax liability balance. $\triangle P P E$ is the change in net PPE.

$\Delta E$ is change in earnings, while $\Delta \mathrm{NA}$ is change in total assets (other than cash). $\triangle R D$ is change in R\&D spending, and $\triangle I$ is change in interest expense. $\triangle D I V$ is change in dividends paid, and $C A S H$ is lagged level of cash. $L E V$ is market-based leverage, and $N F$ is the total of net equity and net debt financing obtained during the year. See Appendix III for more detailed definitions of each variable. $*$, **, and *** denote economic significance at the 10,5 , and $1 \%$ levels, respectively. 
TABLE 5

Supplemental Analysis

Current-Year Depreciation DTL and Future Taxes Paid

Panel A: Excluding Full VA Observations

\begin{tabular}{|c|c|c|c|c|c|}
\hline \multirow[t]{2}{*}{$\begin{array}{l}\text { DV } \\
\text { Year }\end{array}$} & & $\begin{array}{c}T X P D / A T \\
\text { Year } \mathrm{t}+1\end{array}$ & $\begin{array}{c}\text { TXPD/AT } \\
\text { Year } \mathrm{t}+2\end{array}$ & $\begin{array}{c}\text { TXPD/AT } \\
\text { Year } \mathrm{t}+3\end{array}$ & $\begin{array}{r}\text { TXPD/AT } \\
\text { Year } \mathrm{t}+4\end{array}$ \\
\hline & Prediction & $\begin{array}{c}\text { Coefficient } \\
\text { (t-stat) }\end{array}$ & $\begin{array}{c}\text { Coefficient } \\
\text { (t-stat) }\end{array}$ & $\begin{array}{c}\text { Coefficient } \\
\text { (t-stat) }\end{array}$ & $\begin{array}{c}\text { Coefficient } \\
\text { (t-stat) }\end{array}$ \\
\hline Intercept & $(+)$ & $\begin{array}{l}0.005 * \\
(1.84)\end{array}$ & $\begin{array}{c}0.006 \\
(1.45)\end{array}$ & $\begin{array}{c}0.004 \\
(1.35)\end{array}$ & $\begin{array}{l}0.005 \\
(1.41)\end{array}$ \\
\hline PTROA $_{t}$ & $(+)$ & $\begin{array}{l}0.116 \text { *** } \\
(25.44)\end{array}$ & $\begin{array}{l}0.097 \text { *** } \\
(20.22)\end{array}$ & $\begin{array}{l}0.084 \text { *** } \\
(17.62)\end{array}$ & $\begin{array}{l}0.075 \text { *** } \\
(14.86)\end{array}$ \\
\hline$D T L \_D E P R \_A T_{t}$ & $(-)$ & $\begin{array}{l}-\mathbf{0 . 0 3 1} * * * \\
(\mathbf{3 . 7 8 )}\end{array}$ & $\begin{array}{l}-0.028 * * * \\
(3.16)\end{array}$ & $\begin{array}{l}-0.023 * * \\
(2.34)\end{array}$ & $\begin{array}{l}-0.025 * * \\
(2.18)\end{array}$ \\
\hline$D T L \_D E P R \_A T_{t}{ }^{*} N O \_P P E_{-} G R O W T H_{t}$ & $(+)$ & $\begin{array}{l}\mathbf{0 . 0 3 7} * * \\
(2.29)\end{array}$ & $\begin{array}{l}0.036 * \\
(1.87)\end{array}$ & $\begin{array}{l}0.037 * \\
(1.90)\end{array}$ & $\begin{array}{l}0.035 \\
(1.64)\end{array}$ \\
\hline NO_PPE_GROWTH $H_{t}$ & (?) & $\begin{array}{r}-0.001 \\
(1.17)\end{array}$ & $\begin{array}{l}-0.001 \\
(1.42)\end{array}$ & $\begin{array}{l}-0.001 \\
(1.33)\end{array}$ & $\begin{array}{l}-0.001 \\
(1.00)\end{array}$ \\
\hline Observations & & 11,379 & 9,578 & 7,892 & 6,425 \\
\hline Fixed Effects & & Ind/Yr & Ind/Yr & Ind/Yr & Ind/Yr \\
\hline Clustered S.E. & & Firm & Firm & Firm & Firm \\
\hline R-squared & & 0.3688 & 0.2948 & 0.2538 & 0.2248 \\
\hline
\end{tabular}


Panel B: Including Full VA Observations

\begin{tabular}{|c|c|c|c|c|c|}
\hline \multirow[t]{2}{*}{$\begin{array}{l}\text { DV } \\
\text { Year }\end{array}$} & \multirow[b]{2}{*}{ Prediction } & $\begin{array}{c}\text { TXPD/AT } \\
\text { Year } \mathrm{t}+1\end{array}$ & $\begin{array}{c}\text { TXPD/AT } \\
\text { Year } \mathrm{t}+2\end{array}$ & $\begin{array}{c}T X P D / A T \\
\text { Year } \mathrm{t}+3\end{array}$ & $\begin{array}{r}\text { TXPD/AT } \\
\text { Year } \mathrm{t}+4\end{array}$ \\
\hline & & $\begin{array}{c}\text { Coefficient } \\
\text { (t-stat) }\end{array}$ & $\begin{array}{c}\text { Coefficient } \\
\text { (t-stat) }\end{array}$ & $\begin{array}{c}\text { Coefficient } \\
\text { (t-stat) }\end{array}$ & $\begin{array}{c}\text { Coefficient } \\
\text { (t-stat) }\end{array}$ \\
\hline Intercept & $(+)$ & $\begin{array}{l}0.008 * * \\
(2.31)\end{array}$ & $\begin{array}{l}0.009 * * \\
(2.01)\end{array}$ & $\begin{array}{l}0.007 * * \\
(2.22)\end{array}$ & $\begin{array}{l}0.007 * * \\
(1.97)\end{array}$ \\
\hline PTROA $_{t}$ & $(+)$ & $\begin{array}{l}0.079 * * * \\
(20.76)\end{array}$ & $\begin{array}{l}0.067 * * * \\
(17.45)\end{array}$ & $\begin{array}{l}0.058 * * * \\
(15.53)\end{array}$ & $\begin{array}{l}0.052 \text { *** } \\
(13.09)\end{array}$ \\
\hline$D T L \_D E P R \_A T_{t}$ & $(-)$ & $\begin{array}{r}0.001 \\
(1.22)\end{array}$ & $\begin{array}{r}0.001 \\
(1.11)\end{array}$ & $\begin{array}{r}0.000 \\
(0.07)\end{array}$ & $\begin{array}{l}0.000 \\
(0.17)\end{array}$ \\
\hline$D T L \_D E P R \_A T_{t} * N O \_P P E_{-} G R O W T H_{t}$ & $(+)$ & $\begin{array}{r}0.000 \\
(0.69)\end{array}$ & $\begin{array}{r}0.000 \\
(0.42)\end{array}$ & $\begin{array}{l}0.001 \\
(1.39)\end{array}$ & $\begin{array}{l}0.001 * * \\
(2.50)\end{array}$ \\
\hline$N O \_P P E \_G R O W T H_{t}$ & (?) & $\begin{array}{l}-0.001 * * \\
(2.38)\end{array}$ & $\begin{array}{l}-0.002 * * \\
(2.52)\end{array}$ & $\begin{array}{l}-0.001 * \\
(1.71)\end{array}$ & $\begin{array}{r}-0.001 \\
(0.80)\end{array}$ \\
\hline $\begin{array}{l}\text { Observations } \\
\text { Fixed Effects } \\
\text { Clustered S.E. } \\
\text { R-squared }\end{array}$ & & $\begin{array}{r}12,962 \\
\text { Ind/Yr } \\
\text { Firm } \\
0.3065\end{array}$ & $\begin{array}{r}11,028 \\
\text { Ind/Yr } \\
\text { Firm } \\
0.2522\end{array}$ & $\begin{array}{r}9,198 \\
\text { Ind/Yr } \\
\text { Firm } \\
0.2206\end{array}$ & $\begin{array}{r}7,590 \\
\text { Ind/Yr } \\
\text { Firm } \\
0.2001\end{array}$ \\
\hline
\end{tabular}

These tables regress taxes paid in future years on the following current year amounts: pretax return on assets, the deferred tax liability for depreciation (entered as a positive number), an indicator variable for firms having no growth in gross PP\&E, and an interaction of the deferred tax liability for depreciation and the no PPE growth indicator variable. All amounts (other than the indicator variable) are scaled by total assets. Panel A excludes firm-year observations with full valuation allowances. Panel B includes firm-year observations with full valuation allowances. *, **, and *** denote economic significance at the 10,5 , and $1 \%$ levels, respectively. 
TABLE 6

Market Valuation of Deferred Tax Balance Sheet Components S\&P 500 Firms

Effect of Tax Bonus Depreciation

\begin{tabular}{|c|c|c|c|}
\hline$D V=P R I C E$ & Prediction & $\begin{array}{l}\text { Low Bonus Depr } \\
\text { Benefit Firms } \\
\text { Coefficient } \\
\text { (t-stat) }\end{array}$ & $\begin{array}{l}\text { High Bonus Depr } \\
\text { Benefit Firms } \\
\text { Coefficient } \\
\text { (t-stat) }\end{array}$ \\
\hline Intercept & $(+)$ & $\begin{array}{l}29.92 * * * \\
(3.93)\end{array}$ & $\begin{array}{l}45.22 * * \\
(2.52)\end{array}$ \\
\hline$N O A$ & $(+)$ & $\begin{array}{l}1.76 * * * \\
(2.76)\end{array}$ & $\begin{array}{l}1.11 * * * \\
(4.06)\end{array}$ \\
\hline NPPE & $(+)$ & $\begin{array}{l}2.02 * * * \\
(3.23)\end{array}$ & $\begin{array}{l}1.74 * * * \\
(5.27)\end{array}$ \\
\hline NPENSION & $(+)$ & $\begin{array}{c}0.11 \\
(0.06)\end{array}$ & $\begin{array}{c}1.26 \\
(1.53)\end{array}$ \\
\hline NOPEB & $(+)$ & $\begin{array}{l}3.99 * * \\
(2.34)\end{array}$ & $\begin{array}{l}2.68 * * * \\
(3.04)\end{array}$ \\
\hline$N F A$ & $(+)$ & $\begin{array}{l}2.37 * * * \\
(2.87)\end{array}$ & $\begin{array}{c}0.17 \\
(0.57)\end{array}$ \\
\hline$A E$ & $(+)$ & $\begin{array}{l}4.39 * * * \\
(3.26)\end{array}$ & $\begin{array}{l}4.53 * * * \\
(5.75)\end{array}$ \\
\hline$L A G \_A E$ & $(+)$ & $\begin{array}{l}2.77 * * * \\
(3.06)\end{array}$ & $\begin{array}{l}1.80 * * \\
(2.37)\end{array}$ \\
\hline$D T A \_S T$ & $(+)$ & $\begin{array}{c}8.16 \\
(1.02)\end{array}$ & $\begin{array}{c}5.38 \\
(1.55)\end{array}$ \\
\hline$D T L \_S T$ & $(+)$ & $\begin{array}{r}5.48 \\
(1.12)\end{array}$ & $\begin{array}{l}-24.88 * * * \\
(3.86)\end{array}$ \\
\hline NET_DEFERRED_LT & $(+)$ & $\begin{array}{l}-1.73 \\
(0.59)\end{array}$ & $\begin{array}{r}0.38 \\
(0.42)\end{array}$ \\
\hline$D E P R \_D T L$ & $(+)$ & $\begin{array}{c}2.52 \\
(1.16)\end{array}$ & $\begin{array}{l}3.77 * * * \\
(4.14)\end{array}$ \\
\hline $\begin{array}{l}\text { Observations } \\
\text { Fixed Effects } \\
\text { Clustered S.E. } \\
\text { R-squared } \\
\end{array}$ & & $\begin{array}{r}648 \\
\text { Ind/Yr } \\
\text { Firm } \\
0.6480 \\
\end{array}$ & $\begin{array}{r}643 \\
\text { Ind/Yr } \\
\text { Firm } \\
0.7950 \\
\end{array}$ \\
\hline
\end{tabular}


Table 6 regresses price per share, three months after fiscal year end, on balance sheet items and abnormal earnings. All independent variables are expressed on a per-share basis. This table is limited to firms in the S\&P 500. As a proxy for firms that were most affected by bonus depreciation, I select firms that are below the median in terms of the PPE replenishment rate (CAPX scaled by lagged net PPE), computed on a 3 year rolling basis. I select this proxy based on the notion that firms with property eligible for rapid tax depreciation lives are less likely to benefit from bonus tax depreciation, while firms with relatively long-lived property will enjoy higher benefits from tax bonus depreciation.

The following items are scaled by number of shares outstanding: $N O A$ (net operating assets), NPPE (net property, plant and equipment), NPENSION (net pension), NOPEB (net other post-employment retirement benefits), $N F A$ (financial assets net of debt), $A E$ (abnormal earnings, estimated as described in Appendix II), $L A G \_A E$ (lagged abnormal earnings), DTA_ST (current deferred tax assets), DTL_ST (current deferred tax liabilities), NET_DEFERRED_LT (net noncurrent deferred tax liabilities, except for deferred tax liabilities associated with depreciation), DEPR_DTL (the deferred tax liability balance associated with depreciation). See Appendix III for all variable definitions. * **, and *** denote economic significance at the 10, 5, and $1 \%$ levels, respectively. 


\section{APPENDIX A, Panel A General Deferred Tax Example}

\section{Ending GAAP Balances, End of Year 1:}

Cash

Depreciable Property

Deferred Tax Liability

Equity

\section{Ending GAAP Balances}

Year 2:
Firm A

Year 1

0 GAAP Depr

100 Tax Depr
Firm B

\begin{tabular}{|c|}
\hline Year 1 \\
0 GAAP Depr \\
0 Tax Depr \\
\hline
\end{tabular}

40

100

40

100

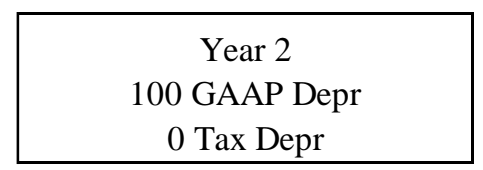

40

100

(100)
100

Cash
Property
Accum. Depr
Deferred Tax Liability
Equity

\section{Year 2} 100 GAAP Depr 100 Tax Depr

Firm A and Firm B are identical, each purchasing a $\$ 100$ piece of equipment near the end of Year 1. Neither firm records GAAP depreciation in Year 1, and Firm B elects to claim no tax depreciation. Firm A, on the other hand, elects accelerated tax depreciation in Year 1 and deducts the full $\$ 100$ purchase price on its Year 1 tax return. Because Firm A deducts an extra $\$ 100$ tax depreciation expense in Year 1, it will save $\$ 100 * 40 \%=\$ 40$ in cash taxes compared to Firm B, but this cash is exactly offset by Firm A's deferred tax liability of \$40. For simplicity, Firm A retains this extra $\$ 40$ in its bank account, rather then spending or investing the amount.

Note that investors can easily observe the extra cash on Firm A's balance sheet, but one question I examine is whether (and how) investors take into account the deferred tax liability on Firm A's balance sheet.

In Year 2, both firms record $\$ 100$ of GAAP depreciation, since the asset will be fully worn out by the end of Year 2. Firm A, which elected accelerated full tax depreciation in Year1, has no tax deduction for Year 2, while Firm B deducts $\$ 100$ of tax depreciation in Year 2. Because Firm B will claim an extra $\$ 100$ of tax depreciation deductions in Year 2 compared to Firm A, it will save an extra $\$ 100 * 40 \%=\$ 40$ in cash taxes in Year 2, compared to Firm A. Neither firm will have a deferred tax liability at the end of Year 2, since the GAAP and tax basis of the property is the same (i.e., is zero in both cases).

Note that by the end of Year 2, the two firms have identical balance sheets, suggesting that they also have identical values at that point. If investors favorably reacted to the excess cash on Firm A's balance sheet in Year 1 and ignored the associated deferred tax liability, then investors would overprice Firm A compared to Firm B in Year 1. 


\section{APPENDIX A, Panel B Growing Deferred Tax Liability Example}

\begin{abstract}
Firm A
Year 1

0 GAAP Depr

100 Tax Depr

Ending GAAP Balances, End of Year 1:

Cash

Depreciable Property

Deferred Tax Liability

Equity

Ending GAAP Balances

Year 2:

Cash
Property
Accum. Depr
Deferred Tax Liability
Equity

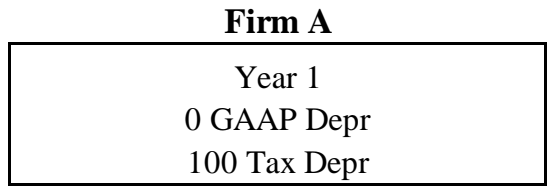

40

100

40

100

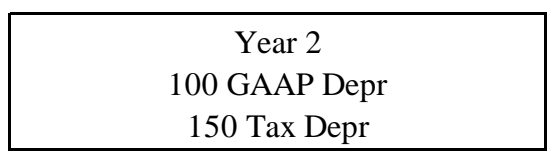

60

250

(100)

Firm B

\begin{tabular}{|c|}
\hline Year 1 \\
0 GAAP Depr \\
0 Tax Depr \\
\hline
\end{tabular}

100

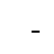

60

250

(100)

60

60

150

The facts are identical to Panel A, except that in Year 2, both firms purchase a $\$ 150$ piece of equipment and fully depreciate it for tax purposes, but record no GAAP depreciation on the new asset. Thus, at the end of Year 2, both firms have cumulatively claimed $\$ 150$ more depreciation deductions for tax than GAAP, which generates excess cash tax savings of $\$ 150 * 40 \%=\$ 60$, and a cumulative DTL of the same amount. Note that his growth in PPE (and the related excess tax depreciation) causes the DTL balance of Firm A to grow from $\$ 40$ to $\$ 60$.

During Year 2, Firm B has $\$ 40$ lower cash tax outflow than Firm A, which results from the reversal of the \$40 DTL that Firm A reported at the end of Year 1. In essence, the $\$ 40$ DTL is repaid to the tax authorities, but this payment is more than offset with a new $\$ 60$ cash tax benefit from the Year 2 asset, generating a net $\$ 20$ increase to Firm A's cash in Year 2. Firm B, on the other hand, receives a $\$ 60$ benefit from excess tax depreciation in Year 2. Thus, when examining Year 1 financial statements, a rational investor would take into account Firm A's Year 1 DTL balance, even if the investor was certain the net DTL balance would continue to grow.
\end{abstract}

\section{Recap of Year 2 Activity}

\section{$\underline{\text { Firm A Firm B }}$}

Tax depreciation, Year 1 asset

Tax depreciation, Year 2 asset

Less GAAP depreciation

Net difference during Year 2

Tax rate

Cash and DTL change, Year 2

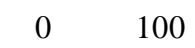

$150 \quad 150$

$100 \quad 100$

i.e., during Year 2, Firm A increases its cash and

DTL by $\$ 20$ and $-\$ 20$, respectively 


\section{APPENDIX B Deferred Tax Data Collection via Perl Scripts}

My study focuses on the portion of the deferred tax liability associated with depreciation, a data item not available in researchers' structured databases. To collect this needed data, the Perl script first downloads $10-\mathrm{K}$ filings from the SEC website. ${ }^{23}$ I then create a new Perl script that locates the effective tax rate (ETR) table within the 10-K filing, as this is typically easier to identify than the deferred tax asset and liability table. The script then identifies the table immediately before and immediately after the ETR table to determine whether either table is the desired deferred tax table. If the deferred tax table is not found, the search is expanded to the second table before/after and finally the third table before/after. If the deferred tax table is not found, the program terminates for that firm year.

After identifying the deferred tax table, the program searches for the depreciation line, searching for "depreciation" and a series of synonyms, such as "fixed assets," "PP\&E," "property," etc. After the program identifies the desired line, the program then captures the depreciation-related deferred tax amount, along with the firm's CIK and the fiscal year end date. In addition, the program also captures the total/net deferred tax asset or liability from the table. This total is then compared to the sum of the deferred tax balances from Compustat, and extracted firm years with footnote detail that vary more than $10 \%$ from the Compustat balance are deleted. It should be noted that this data check step likely results in the deletion of some valid firm-year observations. This is because the tax footnote contains all of the deferred tax amounts, while the Compustat values do not include the portion of deferred taxes that are included in other assets and other liabilities. For example, consider a firm that has only one deferred tax asset, and that asset is properly listed in the deferred tax table. If the resulting amount is small compared the rest of the balance sheet, the firm will likely include the deferred tax asset amount in other assets, rather than break it out in a small deferred tax asset account on the face of the balance sheet. In this example, my script would delete this observation as non-matching.

To determine the scale of the footnote amounts, my program compares the total from the deferred tax table to the total of all Compustat deferred tax accounts. If, for example, the total from the deferred tax table is 1,100 and the total of the Compustat deferred tax accounts is 1.1, then the deferred tax table amounts are divided by 1,000. However, this process will not function when the net deferred tax accounts are exactly zero (usually due to a valuation allowance). In that case, the program collects other tables from the footnotes and attempts to match their scale to the face of the financial statements. If a matching scale is identified in this manner, then that scale is applied to the depreciation deferred tax amount.

\footnotetext{
${ }^{23}$ I thank Andy Leone for making available his script for this downloading process.
} 


\section{APPENDIX B (Continued) Deferred Tax Data Collection via Perl Scripts}

I summarize the primary reasons that a firm-year might be excluded from my sample:

1. The tax footnote does not contain a separate line for the depreciation differences (i.e., the amount is included in the "other" line of the deferred tax footnote).

2. The $10-\mathrm{K}$ is filed in plain text format, rather than HTML (very rare after 2005).

3. A material portion of the deferred tax asset or liability is not reported on the face of the balance sheet as a deferred tax account, but rather is included in "other." This causes the matching process to fail and the firm year is discarded.

4. The firm's tax footnote reverses the order of the prior and current year columns (i.e., it displays the prior year on the left, and the current year on the right).

5. The footnote is displayed in a very unusual way (for example, the balances are displayed as a roll forward table, or the years are in rows rather than in columns).

6. The program was not able to find the ETR table (which serves as the anchor for the deferred tax table search process).

7. The firm describes its deferred taxes in narrative form, rather than in a table. 


\section{APPENDIX C Variable Definitions}

(Compustat mnemonics in parenthesis)

\section{Panel A: Main Model}

PRICE

$N O A$

NPPE

NPENSION

NOPEB

$N F A$

$A E$

DTA_ST

NET_DEFERRED_LT

$D E P R \_D T L$

PPE_SHORT
Price per share, three months after year end, to allow investors time to react to the tax footnote after it is released in the $10-\mathrm{K}$.

Net operating assets, exclusive of NPPE, NPENSION, NOPEB: ((CEQ - NFA [from below]-PPENT-PPLAO+PBPRO-PRBA(TXDBA+TXDBCA- TXDBCL-TXDB))/CSHO).

Net property plant and equipment: (PPENT/CSHO).

Net pension: ((PPLAO-PBPRO)/CSHO).

Net other post-retirement benefits: (PRBA/CSHO).

Net financial assets: ((CHE+INVST(DLTT+DLC+PSTK))/CSHO).

Abnormal earnings, defined as operating earnings (as defined by Laux (2013), less expected operating earnings (last year's net operating assets times assumed cost of capital of 10 percent): ESPX $+0.65 *(\mathrm{INIT} / \mathrm{CSHPRI})-(0.65 *(\mathrm{IDIT}+\mathrm{NOPIO}) / \mathrm{CSHPRI})-$ $0.1 *((\mathrm{CEQ}-\mathrm{NFA}-(\mathrm{TXDBA}+\mathrm{TXDBCA}-\mathrm{TXDBCL}-$ TXDB))/CSHO).

Current deferred tax asset balances: (TXDBCA/CSHO).

Noncurrent deferred tax balances, other than deferred taxes associated with depreciation: (TXDB-DEPR_DTL/CSHO).

The deferred tax liability balance associated with depreciation, collected by Perl script, scaled by shares outstanding (CSHO).

An indicator variable $=1$ if the firm is in the top quartile of shortest GAAP fixed asset lives, zero otherwise. This determination is based on the average ratio of capital expenditures to beginning balance of net PPE over the preceding three years. Firms coded one have the shortest-lived fixed assets: (CAPX/PPENT). 


\section{APPENDIX C (Continued) \\ Variable Definitions}

(Compustat mnemonics in parenthesis)

\section{Panel B: Supplemental Tests (Table 4)}

Excess_Return

$\triangle C A S H$

$\triangle D T L_{-} D E P R$

$D T L \_D E P R$

$\Delta E$

$\triangle N A$

$\triangle R D$

$\Delta I$

$\triangle D I V$

CASH

LEV

$N F$
The dependent variable is the return for the year in excess of a benchmark portfolio using $5 \times 5$ Fama and French portfolios formed on size and book-to-market, computed pursuant to Faulkender and Wang (2006).

Change in cash and marketable securities (CHE) from year t-1 to year $\mathrm{t}$.

Change in balance of the deferred tax liability associated with depreciation (collected from Perl script) from year $\mathrm{t}-1$ to year $\mathrm{t}$.

Level of the deferred tax liability for depreciation (collected by Perl script) at year t-1.DTL_DEPR is expressed as a positive number (even though it is a liability balance), so a positive $\triangle D T L \_D E P R$ corresponds with a growing depreciation-related deferred tax liability balance.

Change in earnings (defined as earnings before extraordinary items, deferred tax credits and investment credits: IB + XINT + TXDI + ITCI) from year $t-1$ to year $t$.

Change in total assets (other than cash) (AT - CHE) from year t-1 to year $\mathrm{t}$.

Change in $R \& D$ spending (XRD) from year t-1 to year $t$.

Change in interest expense (XINT) from year t-1 to year $t$.

Change in dividends paid (DVC) from year $t-1$ to year $t$.

Level of cash and marketable securities (CHE) at year t-1.

Market-based leverage: (DLTT + DLC) / (DLTT + DLC + (PRCC_F * CHSO)).

Total of net equity and net debt financing obtained during the year: (SSSTK - PRSTKC) + (DLTIS - DLTR).

All variables in Table 4 of the Supplemental Analysis (except $L E V, P P E \_S H O R T$ and the dependent variable, Excess_Return) are scaled by lagged market value of equity, and all amounts are also deflated by the consumer price index of 2001, consistent with Faulkender and Wang (2006). 


\section{REFERENCES}

Accounting Principles Board (APB). 1967. Accounting for Income Taxes. Accounting Principles Board Opinion No. 11. New York, NY: APB.

Accounting Standards Committee. 1985. Accounting for Deferred Taxation, Statement of Standard Accounting Practice (SSAP) No. 15. Institute of Chartered Accountants in England and Wales: London.

Amir, E., M. Kirschenheiter, and K. Willard. 1997. The valuation of deferred taxes. Contemporary Accounting Research 14 (4): 597-622.

Amir, E., M. Kirschenheiter, and K. Willard. 2001. The aggregation and valuation of deferred taxes. Review of Accounting Studies 6 (2-3): 275-297.

Ayers, B. C. 1998. Deferred tax accounting under SFAS No. 109: An empirical investigation of its incremental value-relevance to APB No. 11. The Accounting Review 73 (2): 195-212.

Bauman, M. P., and K. W. Shaw. 2016. Balance sheet classification and the valuation of deferred taxes. Research in Accounting Regulation 28 (2): 77-85.

Dotan, A. 2003. On the value of deferred taxes. Asia-Pacific Journal of Accounting \& Economics 10 (2): 173-186.

Faulkender, M., and R. Wang. 2006. Corporate financial policy and the value of cash. Journal of Finance 61 (4): 1957-1990.

Feltham, G. A., and J. A. Ohlson. 1995. Valuation and clean surplus accounting for operating and financial activities. Contemporary Accounting Research 11 (2): 689-731.

Financial Accounting Standards Board (FASB). 1984. Statement of Financial Accounting Concepts No. 5, Recognition and Measurement in Financial Statements of Business Enterprises. Norwalk, CT: FASB.

Financial Accounting Standards Board (FASB). 1992. Statement of Financial Accounting Standards No. 109, Accounting for Income Taxes. Norwalk, CT: FASB.

Financial Accounting Standards Board (FASB). 2008. Statement of Financial Accounting Concepts No. 6 (As Amended), Elements of Financial Statements. Norwalk, CT: FASB.

Financial Accounting Standards Board (FASB). 2010. Statement of Financial Accounting Concepts No. 8, Conceptual Framework for Financial Reporting. Norwalk, CT: FASB.

Financial Accounting Standards Board (FASB). 2015. Accounting Standards Update 2015-17, Income Taxes (Topic 740), Balance Sheet Classification of Deferred Taxes. Norwalk, CT: FASB. 
Finley, A. R., A. Ribal, and E. H. Weisbrod. 2017. The Information Content of a Valuation Allowance Release and How External Monitors Respond to this Signal. Working paper, Claremont McKenna College.

Givoly, D., and C. Hayn. 1992. The valuation of the deferred tax liability: Evidence from the stock market. The Accounting Review 67 (2): 394-410.

Graham, J. R., J. S. Raedy, and D. A. Shackelford. 2012. Research in accounting for income taxes. Journal of Accounting and Economics 53 (1-2): 412-434.

Guenther, D. A., and R. C. Sansing. 2000. Valuation of the firm in the presence of temporary book-tax differences: The role of deferred tax assets and liabilities. The Accounting Review 75 (1): $1-12$.

Guenther, D. A., and R.C. Sansing. 2004. The valuation relevance of reversing deferred tax liabilities. The Accounting Review 79 (2): 437-451.

Hanlon, M., and S. Heitzman, S. 2010. A review of tax research. Journal of Accounting and Economics 50 (2-3): 127-178.

Laux, R. C. 2013. The association between deferred tax assets and liabilities and future tax payments. The Accounting Review 88 (4): 1357-1383.

Lynn, S. G., C. Seethamraju, and A. Seetharaman. 2008. Incremental value relevance of unrecognized deferred taxes: Evidence from the United Kingdom. Journal of the American Taxation Association 30 (2): 107-130.

Sansing, R. 1998. Valuing the deferred tax liability. Journal of Accounting Research 36 (2): 357-363.

Thomas, J., and F. Zhang. 2014. Valuation of tax expense. Review of Accounting Studies 19 (4): $1436-1467$. 